\title{
Five critical questions of scale for the coastal zone
}

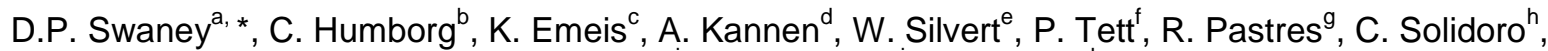 \\ M. Yamamuro', Y. Hénocque ${ }^{j}$, R. Nicholls ${ }^{k}$
}

\begin{abstract}
${ }^{a}$ Dept. of Ecology \& Evolutionary Biology, Cornell University, Ithaca NY, USA
b Dept. of Applied Environmental Science \& Stockholm Resilience Centre, Baltic Nest Institute, Stockholm University, 10691 Stockholm, Sweden

${ }^{c}$ Dept. of Geosciences, University of Hamburg, Bundesstr. 55, 20146 Hamburg, Germany

${ }^{d}$ Dept. of Human Dimensions of Coastal Areas, Helmholtz-Zentrum Geesthacht, Centre for Materials and Coastal Research, Max-Planck Str. 1, 21502 Geesthacht, Germany

e Centro de Ciencias do Mar, Universidade do Algarve, 8000 Faro, Portugal

${ }^{\dagger}$ School of Life Sciences, Napier University, 10 Colinton Road, Edinburgh EH10 5DT, Scotland, United Kingdom

${ }^{9}$ Dipartimento di Chimica Fisica, University of Venice, Italy

${ }^{\mathrm{h}}$ Istituto Nazionale di Oceanografia e di Geofisica sperimentale - OGS, 34010 Sgonico - Zgonik, Italy

i Dept. of Natural Environmental Studies, Graduate School of Frontier Sciences, The University of Tokyo, Kashiwa, Chiba, Japan

j French Research Institute for the Exploitation of the Sea, IFREMER, 155 rue Jean-Jacques Rousseau Issy-les-Moulineaux 92138, France

${ }^{\mathrm{k}}$ School of Civil Engineering and the Environment, University of Southampton, Highfield, Southampton SO17 1BJ, UK
\end{abstract}

\author{
*: Corresponding author : D. P. Swaney, email address : dps1@cornell.edu ; \\ christoph.humborg@itm.su.se ; kay.emeis@zmaw.de ; andreas.kannen@hzg.de ; bill@silvert.org ; \\ p.tett@napier.ac.uk ; pastres@unive.it ; csolidoro@inogs.it ; yamamuro@k.u-tokyo.ac.jp ; \\ Yves.Henocque@ifremer.fr ; R.J.Nicholls@soton.ac.uk
}

\begin{abstract}
:
Social and ecological systems around the world are becoming increasingly globalized. From the standpoint of understanding coastal ecosystem behavior, system boundaries are not sufficient to define causes of change. A flutter in the stock market in Tokyo or Hong Kong can affect salmon producers in Norway or farmers in Togo. The globalization of opportunistic species and the disempowerment of people trying to manage their own affairs on a local scale seem to coincide with the globalization of trade. Human-accelerated environmental change, including climate change, can exacerbate this sense of disenfranchisement. The structure and functioning of coastal ecosystems have been developed over thousands of years subject to environmental forces and constraints imposed mainly on local scales. However, phenomena that transcend these conventional scales have emerged with the explosion of human population, and especially with the rise of modern global culture. Here, we examine five broad questions of scale in the coastal zone :
\end{abstract}


(1) How big are coastal ecosystems and why should we care ?

(2) Temporal scales of change in coastal waters and watersheds: Can we detect shifting baselines due to economic development and other drivers ?

(3) Are footprints more important than boundaries ?

(4) What makes a decision big? The tyranny of small decisions in coastal regions.

(5) Scales of complexity in coastal waters: the simple, the complicated or the complex ?

These questions do not have straightforward answers. There is no single "scale" for coastal ecosystems; their multiscale nature complicates our understanding and management of them. Coastal ecosystems depend on their watersheds as well as spatially-diffuse "footprints" associated with modern trade and material flows. Change occurs both rapidly and slowly on human time scales, and observing and responding to changes in coastal environments is a fundamental challenge. Apparently small human decisions collectively have potentially enormous consequences for coastal environmental quality, and our success in managing the effects of these decisions will determine the quality of life in the coastal zone in the 21st century and beyond. Vigilant monitoring, creative synthesis of information, and continued research will be necessary to properly understand and govern our coastal environments into the future.

\section{Highlights}

We examine five aspects of "scale" we believe to be important for the coastal zone. Conventional definitions of scale include spatial and temporal dimensions. - The "Homogecene" coastal zone is subject to recent pressures of globalization. - The "tyranny of small decisions" is a major challenge to environmental governance. "Scale of complexity" applies to both understanding processes and decision making.

Keywords : scale ; coastal management ; governance ; Fishery management ; regime shift ; biogeochemistry 


\section{Introduction}

The social and ecological systems that comprise human society and its living space are becoming increasingly globalized. From the standpoint of understanding ecosystem behavior, it is getting harder to model a system within their apparently well-defined boundaries because these are ceasing to be the relevant ones. A flutter in the stock market in Tokyo or Hong Kong can affect salmon producers in Norway or farmers in Togo. Concurrent with the globalization of trade, we are witnessing the globalization of the distribution of opportunistic species and the disempowerment of people attempting to manage their own affairs on a local scale. Climate change, as well as other human-accelerated environmental change, can really exacerbate this sense of disenfranchisement. The structure and functioning of coastal ecosystems has evolved over millennia, subject to environmental forces and constraints imposed mainly by local boundaries of catchment and shore, not human culture. However, phenomena that transcend these local scales have emerged as human populations have increased, and especially with the rise of modern global culture. Much of the science of coastal waters is based on abstract considerations of ecosystem behavior in the absence of human -perturbations", such as long-distance transport of materials, introduction of new species, and human accelerated climate and land use change. How can we keep up with the change in scales (temporal and well as spatial) associated with such human activities? What tools can we employ to help people and policymakers to remain in charge in a meaningful manner?

\section{Some critical questions of scale for the coastal zone:}

1) How big are coastal ecosystems and why should we care?

2) Temporal scales of change in coastal waters and watersheds: Can we detect shifting baselines due to economic development and other drivers?

3) Are footprints more important than boundaries?

4) What makes a decision big? The tyranny of small decisions in coastal regions.

5) Scales of complexity in coastal waters: the simple, the complicated or the complex?

\section{1) How big are coastal ecosystems and why should we care?}

The short answer to the first half of the question is that coastal ecosystems, and the various entities which comprise and interact with them, span a range of scales, depending upon the definition of -scale" (see Appendix 1, supplementary material) and the issues to be analyzed. For example, an analysis of nutrient inputs and eutrophication might be conducted along the boundaries of the catchment-coast continuum, or include an analysis of agricultural systems and businesses at global, continental (e.g. Europe or at least EU wide) or national policy scales. The question of scale is a fundamental challenge for coastal research necessitating a variety of research approaches and requiring extrapolation from mesocosms in many cases (Boynton et al. 2001). While it has become a truism that -scale" is an important dimension in coastal science and management, it is critical to distinguish its manifestation in different categories of processes (Fig. 1). Physical scale effects are often propagated via intermediatescale processes, (e.g. energy transferred via turbulent eddies from large areas and time scales to the smallest scales of turbulent mixing). Temporal scales tend to correlate linearly with spatial scales, while ecological effects can jump" intermediate scales or simultaneously be manifest on different scales (e.g., long-lived species and their structures which tend to result in -menory" effects in ecosystems), so it is more difficult to consider a single time scale 
corresponding to the spatial scale of an ecosystem. Governance entities, including government agencies, local communities, and the full range of -stakeholder" groups in the coastal zone, exhibit influence at overlapping scales, and are subject to hierarchies and gaps in coverage. Drivers exhibit overlapping asymmetrical effects (large scale drivers affect small scale systems, but not conversely). These effects make selection of a single scale of analysis problematic, and the result is that we must consider a superposition of scales in most cases involving governance of coastal waters (Solidoro et al., 2010a).

$<$ Figure 1 near here $>$

The answer to the second half of the question is fairly obvious: Because the response of coastal ecosystems to various pressures (changes in material inputs, freshwater discharge, temperature, etc) depends on how big they are." Studies of coastal ecosystems frequently attempt to relate physical or biological processes within the systems to characteristic scales, (volume, area, residence time). During the first decade of the Land Ocean Interactions in the Coastal Zone program (LOICZ ), coastal nutrient budgets were developed for coastal systems spanning six orders of magnitude in surface area (Smith et al., 2005; Swaney et al., in press). Based on some statistical analyses of LOICZ coastal nutrient budgets, it appears that the net ecosystem metabolism of coastal systems varies inversely with system size, i.e., large systems with long residence times have relatively low metabolic rates, possibly because they are colder, deeper, darker, and may have lower nutrient inputs/volume on average than smaller systems (Fig. 2). This allometric relationship (1, supplementary materials) appears to be true whether the systems are heterotrophic (ecosystem respiration exceeding production) or autotrophic (production exceeding ecosystem respiration). Robust statistical analyses using the Olmstead-Tukey test (Olmstead and Tukey, 1947; Sokal and Rohlf, 1995) indicate that such inverse relationships are significant for net-autotrophic systems using either residence time or area as a scale measure, and for net heterotrophic systems using residence time. Other studies have noted that small land margin systems (e.g. coastal lagoons) have relatively high primary and secondary productivity and fish catches compared to larger coastal systems (Houde and Rutherford, 1993). If the productivity of a coastal system varies strongly with its size, then it is likely that management of the system should also vary with size, i.e., one management or decision-making approach should not apply to coastal systems across all scales (Kannen et al 2008). So it seems that for coastal systems, one size does not fit all.

$<$ figure 2 near here $>$

The size question is also relevant to the globally-aggregated productivity of coastal regions. It is well known that coastlines vary in length depending upon the resolution with which they are measured. This fractal property may also apply to the distribution of sizes of various coastal features: for example, Pareto (power law) distributions are well-known to describe island areas, lakes, and other natural features. If they apply to coastal seas, embayments, estuaries and lagoons, it suggests that small systems are numerically dominant, and possibly critical to overall coastal productivity. The nonlinear nature of the response of these systems (Folke et al., 2004), and their associated ecosystem services (e.g., Barbier et al., 2008) as well as their spatial and temporal variability (Luisetti et al., 2011) implies that there should be a strong scale-dependence in many of the benefits humans obtain from coastal ecosystems as well (Koch et al., 2009). The combination of an uneven distribution of the size of coastal ecosystems, and the nonlinear variation of ecological processes and ecosystem services to ecosystem scale implies that simple area-based extrapolations of estimates of the global 
contribution of coastal regions probably underestimate their value to human society (Duarte et al., 2008)..

While the above can be considered a variation of the well-established idea that localized hotspots" or patches" provide most of the activity in most ecosystems, it suggests that hotspots are dominant features of the coastal zone. Another view is that the cumulative value of a collection of many small, highly-variable autotrophic and heterotrophic systems is simply the (relatively low) productivity of the mean value of the collection. Averaging out the extremes of productivity of the components of a large system is just a property of the central tendency of the statistics, and so the apparent inverse relation between size of a system (measured in various ways) and magnitude of processes (metabolism, percent nutrient export, etc) is the result. Are these fundamental issues relevant to the governance of coastal systems, or is it simply another manifestation of environmental heterogeneity of which we must be mindful in management?

\section{2) Temporal scales of change in coastal waters and watersheds: Can we detect shifting baselines and regime shifts due to economic development and other drivers?}

History is long; human memory is short. For most of their history, coastal ecosystems have evolved and developed under the joint influence of their local (though sometimes large) coastal watersheds and oceanic influences. Human accelerated environmental change, particularly landscape transformations, typically beginning with settlement of colonial regions, but also associated with the rise of new technologies, has dramatically increased the influence of terrestrial drivers. These changes include increased nutrient loads and pollutants from a variety of sources; altered hydrological and sediment transport regimes caused by impoundments, other hydraulic engineering structures, and increased impervious surface; and introduced invasive species from microbes to mammals. Many of these effects have been shown clearly in the Chesapeake by Brush (2008) using paleoecological methods and historical records (Fig. 3), and similar impacts are widely recognized in other watersheds (Meybeck, 2003; Turner and Rabalais, 2003; Swaney et al., 2006; Billen et al., 2007; Humborg et al., 2007; Nixon et al., 2008; Solidoro et al., 2010b). Many changes are due to increases in infrastructure - impervious surface, land drainage, damming, hardened coastline, dredging to facilitate shipping, and consequent modification of watershed and estuarine hydrological, biogeochemical and biological processes. For example, the joint effects of dams in reducing sediment transport and projected sea level rise in increasing inundation poses a major threat to the world's major deltaic systems (Ericson et al., 2006; Woodroffe et al., 2006; Syvitsky et al., 2009). Several studies (e.g., Restrepo et al., 2006; Richmond et al., 2007) have demonstrated the negative impact of runoff and sediment loading to seagrasses and coral systems, even beyond what is typically perceived to be the immediate receiving waters of coastal watersheds, and the need for incorporating watershed management in dealing with these impacts.

While the increase in nutrient loads caused by changes in agriculture practices and land use which occurred during last century triggered eutrophication phenomena over most European and American coastal areas, a reversal in eutrophication trends (so called oligotrophication) is being seen in recent decades in many areas (Stockner et al. 2000, Nixon et al., 2009; Mozetic et al, 2010), probably because of the enforcement of new environmental protection legislation in these regions. This suggests on the one hand that eutrophication trends are reversible, but on the other opens the question of unintended consequences for secondary production, including fisheries (Nixon et al., 2009) 
Direct human modification of coastal lands and waters also continues to increase. Lotze et al. (2006) showed patterns of species and habitat loss, species invasions, and water quality degradation in estuaries and coastal seas around the world. Fifty-five percent of the mangrove areas on the coast of Thailand were lost between 1961 and 1996 through the development of shrimp farming, urban development, mining and other factors, though in recent years there has been some recovery (Giesen et al., 2006). The increasing prevalence of fin- and shellfish aquaculture in coastal waters has significantly modified their nutrient regimes in some cases, either through the direct introduction of nutrients in food or the removal of nutrients with harvest (e.g., Yamamuro et al., 2006). Increased port development and shipping activity associated with the growth of trade has affected coastal water quality in and near ports, including the dredging of channels for increasingly large cargo vessels (Wolanski, 2006). Such disturbance may cause increases in turbidity, alter the flows and flowpaths, and adversely affect fish nursery areas.

Oceanic and climatic influences are also changing and will continue to do so. The coastal zone in the sense of LOICZ (-200 m depth to $+200 \mathrm{~m}$ ) has been shaped by global (eustatic) sea level variations and associated cycles of transgressions and regressions over geological time scales. Reconstructions of (eustatic) sealevel change over the last few hundred thousand years suggest that the present sea level is near the maximum reached over the last 450,000 years. Isostatic (regional) sea level varies in present-day coastal zones, but there is now unequivocal evidence for a small, but crucial, eustatic sea level rise caused mainly by thermal expansion of sea water (Bindoff et al. 2007). Projections of sea level change through 2100 AD predict an increase of between $20 \mathrm{~cm}$ and $50 \mathrm{~cm}$ in global mean sea level, not including expected regional effects of increased storm surge height or frequency (Fig. 4. Bindoff et al 2007). While this increase may not seem to be dramatic, it could have consequences for coastal protection, and severe ones for extant tidal flats. Whether situated in estuaries, deltas, or on tidal coasts, these play important roles as specific coastal habitats, biodiversity hot spots, and for mitigation of nutrient fluxes from land to sea in the coastal zone. It is particularly dangerous to sinking deltas (Syvitsky et al., 2009). In the geological past, the coastal zone was effectively a "ramp" that accommodated rising/falling sea level by landward/seaward displacement of individual sedimentary and coastal regimes. That degree of spatial freedom is reduced when the coast is enforced by dikes and other structures ("habitat squeeze"). In the narrowing strip between an advancing sea and a fixed coastline, energy of the water increases and results in preferential selection of coarse sediments; fine particles and organic matter are less effectively retained, and are advected to adjacent deeper water. Among other effects, this can decrease areas of tidal flats, and modify river deltas (Fagherazzi et al. 2006).

$<$ fig 4 near here $>$

The addition of increased storm activity and flooding superimposed on sea level rise projections is problematic. For example, combined storm surge and sea level rise is projected to pose a risk of flooding to the Mekong Delta, despite extensive damming upriver in China (Hoa et al., 2007). Increasingly, large-scale linkages are being recognized between atmospheric phenomena (such as the Southern Oscillation, ENSO, or the North Atlantic Oscillation, NAO) and the variation of intensity of regional weather patterns (so called "teleconnections"; Wallace and Gutzler, 1981). 
Floods and droughts are not the only outcomes of teleconnections. Winter temperature, which

A problem shared by many coastal ecosystems subject to changes in terrestrial, oceanic or climatic influences is the lag between cause and effects: we lack early warning indicators of sudden ecological responses to change. Many coastal ecosystems are exposed to gradual changes (climate change, nutrient loading, fishing pressure etc) and are conventionally

$<$ figure 5 near here $>$

assumed to respond smoothly to these changes. However, this is not always the case. Examples of abrupt ecological responses to environmental change include:

- Human-supported species invasions, especially through ballast water transfer (Carlton, 1999; 2001).

- Invasions driven by climate change favoring one species over another, as when a new species is able to displace existing species (Schluter et al., 2008;.Cheung et al., 2009)

- Natural cycles which involve drastic changes, such as long-term cycles in fish stocks (Silvert and Smith 1981, Silvert 1983, Silvert and Crawford 1988; Alheit and Hagen, 1997).

- "Regime shifts" driven by climate change, pollution or overfishing (deYoung et al., 2008).

Increasing numbers of studies show that smooth changes can be interrupted by abrupt transitions to a new state (e.g., Folke et al., 2004; Duarte et al., 2008), so called regime shifts, One perception of regime shifts is that they are transitions from one quasi-stationary state of a system persisting for several years and characterised by low-frequency variability to another stable state with a transition period of a few years. Gradual and possibly disparate changes have little effect until they surpass a threshold, at which the nature and extent of feedbacks in the system change, leading to an abrupt transition. The availability of data of sufficient duration to see these effects has severely limited the identification of regime shifts in the past. However, both theoretical and empirical observations suggest that increased variance of one of several of the variables characterising ecosystems serves as an early warning indicator for an impending threshold (Brock and Carpenter, 2006). And although there are suggestions that regime shifts can be triggered by immediate human action, most regime shifts reported so far appear to be linked to underlying climatic changes.

Research into the non-linear dynamics of ecosystems has implications for management frameworks (Duit and Galaz, 2008), which still tend to manage ecosystems as steady-state or smoothly changing systems and assume that such changes are reversible. Such policies lead to unsustainable futures. Both natural and anthropogenic regime shifts are important to delineate: indicators are needed in order to design governance structures that permit adaptive management and an ecosystem approach.

Temporal scales related to lag times between cause and effect (in DPSIR terminology between pressures, state changes and impacts) can play a critical role in dynamics and abrupt 
transitions in natural processes, but the same can be said for the institutional response, i.e., the time delay between problem recognition, policy development and political commitment/support to implement a new policy. This can be illustrated by the Multiple Streams framework developed in political sciences (see Zahariadis 2007 on the framework or Meijerink 2005 for an example).

Here, the assumption is that a problem stream" (the shifting baseline) develops over time. Some scientists might initially recognize it, and subsequently recognition could grow (building a so-called -epistemic community", see Haas 1989 on epistemic communities or Meijerink 2005 for an example). In response to the problem stream and partly in parallel to it, a policy stream develops, e.g. civil servants or NGOs developing proposals for a new policy, but unable to implement it for lack of political support, funding and resistance to change and its implications, a situation termed -ecosocial anomie" (Limburg and Waldman, 2009) develops. The situation lasts until either the new ideas become mainstream or - typically due to a crisis/catastrophe - a Window of Opportunity (WO) opens. Examples can be found in the development of Dutch coastal defense strategies (Meijerink and Dicke, 2008, Meijerink 2005). In the Netherlands, the need for strengthening coastal defense structures had been recognized, including development of implementation plans, for two decades before a 1953 flood triggered the opening of a WO for implementation.

Such processes, in which a problem stream, a policy stream and a political stream must converge before policy changes can take place, are fairly common. Other examples include the fight against eutrophication of the North Sea, the ban of open access clam fishing and the initialization of a clam aquaculture system in the lagoon of Venice, and the establishment of National Parks in the German Wadden Sea.

\section{3) Are footprints more important than boundaries?}

There is an increasing awareness in the ICZM community of the importance of catchment/coast coupling: the recognition that in many coastal areas, coastal management cannot be separated from watershed management. (In the context of estuaries and related coastal systems, Wolanski (2007) refers to the processes that bear on these questions as estuarine ecohydrology."). The catchment boundary is a well-defined, natural boundary for understanding hydrological and nutrient linkages between catchment and coast, and even to island or reef systems proximal to the coast (Richmond et al., 2007).

However, infrastructural changes within coastal watersheds can blur or otherwise modify watershed boundaries. Demands for water for agriculture or drinking water can effectively capture parts of neighboring catchments via impoundments and pipelines (as in the New York City reservoir systems) or more dramatically by effectively rerouting major river systems (e.g., in China). Increases in impoundment volumes of dams typically results in increased evaporation, effectively reducing the net precipitation to the watershed and subsequent river flow. Increased storage and aging" of riverine water affects sediment and nutrient loads as well (Vörösmarty et al, 1997); dams are typically associated with decreased sediment load downstream of the dam due to sediment retention, and the reduced flow downstream also has a lower capacity for sediment transport, which can result in both increased siltation and starved deltas. Impoundments also are often responsible for nutrient trapping, notably silicon, and can severely alter downstream nutrient ratios and associated plankton species distributions (Humborg et al., 2006).

In contrast to the catchment boundaries of coastal systems, the last decade has seen the ubiquitous - arbon footprint" emerging as a touchstone of the environmental movement to alert people to their impact on atmospheric $\mathrm{CO}_{2}$ levels and earth's climate (Wiedmann and 
Minx, 2008). The ecological footprint (Wackernagel and Rees, 1996) has been used more broadly to emphasize the dependence of individuals on ecosystem services globally. The foodshed" (Wedden, 1929) or foodprint" (Billen et al., 2009) takes into account the area required to produce agricultural goods required to meet the food requirements of a population, and is thus related directly to the nutrient demands of cities and other concentrations of human population (Fig. 6). A benefit of the footprint concept is its emphasis on bringing awareness of the relationships between local, individual material consumption and distant, diffusely distributed production. A peculiarity of the ecological footprint concept is that it doesn't translate directly into a specific geographic location, but rather represents a hypothetical area of land required to sustain an ecosystem, produce food, or absorb $\mathrm{CO}_{2}$. In contrast, the foodprint" attempts to associate a real" region with the food supply of an urban population (Billen et al., 2009). Historically, the foodprint" of most cities was largely based on local or regional food production. For some cities (e.g. Paris; Billen, 2009) this may still be true; for others (e.g. New York), food supply is inseparable from the global transportation system.

$<$ figure 6 near here $>$

From the standpoint of nutrient loading, watershed nutrient accounting methods have been used to infer the net cross-boundary nutrient inputs to watersheds from the most significant sources (net food/feed transport, fertilizer, and in the case of nitrogen, atmospheric deposition and biological $\mathrm{N}$-fixation) that have been related to nutrient export from watersheds to coastal waters (Howarth et al., 1996; Boyer et al., 2002; Russell et al., 2008; Fig. 7). These methods, cousins of the various footprint methodologies in that they relate local impacts (both withinwatershed and coastal nutrient loads) to transboundary fluxes, reveal the increasing importance of these fluxes in this age of globalization (aptly termed the Homogecene" in the context of biotic homogenization and reduced biodiversity; Rosenzweig, 2001; Rooney, 2007). Nutrient inputs to coastal watersheds are seen to be increasingly related to changes in food preferences and other market trends (more meat/less grain, corn for processed food and biofuels, etc), long-distance transport of nutrients in food and feed across catchment boundaries, and associated increases in atmospheric $\mathrm{N}$ deposition related to vehicular emission sources.

Some material flows to coastal waters (water, sediment, silica) seem to be largely constrained by catchment boundaries and human activities therein. Others (nitrogen, phosphorus) may be more tied to trade and other transboundary effects. In addition, the structure and responses of coastal ecosystems themselves may be changing in response to species flows and resulting changes in biodiversity associated with the onset of the Homogecene (Lotze et al., 2006; Levrel, 2007); one example is the transformative effect of the zebra mussel in North American waters and their biogeochemistry. How can we adapt our thinking and management strategies for coastal waters to these realities?

$<$ figure 7 near here $>$

\section{4) What makes a decision big? The tyranny of small decisions in coastal regions}

Scale" applies to other dimensions beyond time and space. Human decision making is also characterized by a range of scales, from deciding what to have for lunch, to deciding whether or not to go to war. However, most human decisions are small, made by individuals, and are often assumed to have few obvious consequences beyond the decision at hand. Kahn (1966) examined the consequences to the market of cumulative effects of apparently independent 
individual decisions and concluded that they can yield undesirable consequences. William Odum (1982) discussed the phenomenon in the context of the environment, noting the example that no one decided to eliminate $50 \%$ of coastal marshlands of Connecticut and Massachusetts between 1950 and 1970, though this is what happened. Ehrlich and Kennedy (2005) noted that the ethics of decision making is unclear, that there is a need for a focus on how people make decisions affecting the environment, and called for a Millenium assessment of human behavior." A recent, provocative piece in the New York Times (Gertner, 2009; Marx, et al., 2007), suggesting that the human brain may be -wired" to give environmental issues like climate change relatively low priority, only increases the urgency of such work. Regulations and governance presumably should protect environments from gross negligence and irresponsible decisions, but is it possible to safeguard vulnerable regions from these incremental effects of small decisions?

Coastal regions seem disproportionately vulnerable to the cumulative effects of unintended bad" choices because of their relatively high population densities $(45 \%$ of the world's population lives in the $10 \%$ of land area defined by LOICZ as the -oastal zone"; Crossland et al., 2005). Probably more to the point, the rate of migration to coastal regions is higher than to other regions, the result of millions of individual decisions with potentially disastrous consequences. In addition, choices that were relatively innocuous even a few years ago are today more risky due to combined effects of increased vulnerability (i.e., a shifted baseline) and an amplifier effect on consequences of choices due to the nature of modern trade. Historically, most of the small decisions of daily life had little impact beyond local households. Prior to modern food distribution systems, both were procured from local lands or waters. As nutrient accounting can show, the distribution of food and feed can play a dominant role in the level of riverine nutrient fluxes to coastal waters. Modern transport methods assure the arrival of foods across continental scales in a matter of hours or days, thereby guaranteeing a market for fisheries in (previously) remote regions. Fish or fowl for dinner? The fish may have been swimming in coastal waters on the other side of the world a few days before (Berkes et al., 2006). The fowl may be raised in a factory farm, fed on fishmeal from thousands of kilometers away, but the farm discharges waste to local coastal waters.

The world's coastal ecosystems see the direct effects of human activity for the simple reason that more humans live near coastlines, or along major rivers, than in continental interiors far from waters, and are thus especially sensitive to them. This is not an accident of history, but the collective result of individual decisions over time, based on proximity to jobs and other economic opportunities, quality of life, and many other factors all ultimately related to the proximity to coastal waters and their services to humans. Whether the waters support transport and trade, fishing/aquaculture, recreation, serve as a disposal system for sewage and industrial waste, or all of the above, they provide value (i.e., ecosystem services) to the earth's coastal lands, and thus concentrate human populations (UNEP, 2006).

However, the decision to live in coastal areas can ultimately have a dark side, as recent experience with natural disasters in Banda Aceh, New Orleans, Haiti, and Japan has shown. Highly populated coastal regions are especially vulnerable to extreme events of geological or meteorological origin. When the catastrophic, magnitude 8.7 Lisbon earthquake of 1755 rang church bells all over Europe, they tolled for the tens of thousands of lives lost in the quake, the accompanying tsunami and fires, which leveled most of Portugal. The January, 2010 magnitude 7.0 earthquake that struck Port au Prince, Haiti, killed hundreds of thousands and caused devastating damage to infrastructure and personal property in the billions. Both of 
these coastal cities were local centers of population and commerce. While Port au Prince saw no post-quake tsunami, the relative increase in devastation caused by the less powerful Haitian quake (compared to the Portuguese quake) can be seen as a direct result of the relative increase in population density and development in this coastal city. The more recent magnitude 9.0 earthquake and tsunami in northern Japan, and associated nuclear plant catastrophe, shows that even the world's most technologically sophisticated countries are vulnerable. Tsunamis and hurricanes can wreak catastrophic destruction in the modern day, densely populated coastal zone simply by virtue of the number of people deciding to live there; risk to life and property in coastal regions increases in proportion to population density and development even in regions of quality infrastructural engineering and design.

Increasingly, coastal zone governance turns to engaging -stakeholders" at the local scale as well as scientific expertise (e.g. Tompkins et al., 2008) in the hope of equitable solutions and grass roots support. Stakeholder participation has helped to mitigate or solve many conflicts in coastal areas, particularly at local scales, but Bille (2006), in his discussion of the itlusions" of coastal zone management, notes that one illusion is the notion that consensus in human groups is prevalent at small scales. Stojanovic and Barker (2008) discuss several problems of coastal governance through -eastal partnerships" of institutional stakeholders. If consensus is an illusion even in small groups which are deciding questions of governance for small systems, what chance is there for larger systems?

In fact, governance of small coastal systems may be especially difficult because of the numbers of institutions involved. Murawski (2007) refers to this as the paradox of scale": the smaller the geographic scale used to define an ecosystem, the more entities are involved in decision making (Fig. 8).

$<$ figure 8 near here $>$

In addition to scale issues, spatial disconnections, e.g. between decisions upstream and distant environmental consequences downstream, often complicate governance, much as lags between actions and consequences do in the time dimension. Major policy decisions, such as undertaking the massive redistribution of river waters to serve the needs of irrigation and drinking water as is being done with the Changjiang River in China (Xue et al., 2007), can have fairly direct environmental implications downstream. Reducing river flows in coastal areas changes the salinity regime, moving the salt front upstream and potentially increasing the risk of groundwater intrusion of salinity and contamination of drinking water supplies (Xue et al., 2007). Reduction of river flow means a concomitant reduction of sediment transport from upland soils, potentially starving river deltas of sediment. The episodic nature of sediment transport (Xu et al., 2005) and its redistribution in the river network is an especially problematic aspect of sediment management and a source of uncertainty. Woodroffe et al. (2006) point out that while sediment processes are well understood at small time scales because of reliable short-term fluid dynamics, and long time scales ( $>1000$ years) due to the availability of stratigraphic analyses, uncertainties are highest at the intermediate time scales most relevant to managing sediment. Indirect effects can be subtler: introduction of invasive species, shifts in nutrient ratios and corresponding ecosystem changes can easily result from changes in flow regime (Li et al., 2007). All of these flow-related catchment phenomena illustrate the obscuring effect of the spatial dimension on relationships between decisions (large or small) made upstream and consequences (often large) in downstream coastal waters. 


\section{5) Scales of complexity in coastal waters: the simple, the complicated or the complex?}

As pointed out by Dennison (this volume) Glouberman and Zimmerman (2002) have differentiated between simple, complicated and complex classes of problems and management in the context of the Canadian medical establishment. This distinction between categories of problems also applies to the tools available to deal with them. Simple problems can be characterized by simple models (recipes); complicated problems by more complicated models. Truly complex problems or phenomena often transcend the capability of current models, or decision processes.

Ecological modelers have recognized for years that models can exhibit nonlinear and often counterintuitive behavior, and so must be created and used judiciously (e.g., Silvert, 2000; Sterman, 2002). Solving the -Goldilocks problem" of matching the appropriate level of model detail to the question at hand is a Holy Grail of modeling; on the one hand, simple models are desirably parsimonious, even though many can exhibit complex behavior (Swaney et al., 2008). On the other hand, models that are too simple (e.g., not - bigeochemical" in the sense of Tett and Wilson, 2000) run the risk of being unrealistic and, if used as a guide for management, conceivably dangerous. Calls for new integrated modeling tools (e.g., Kroeze, et al., 2008) are appropriate and necessary, but probably not sufficient.

The appropriate level of model complexity depends on the problem to be addressed, and the data available to drive it. While in many cases complex models are needed for use in predicting environmental status of coastal waters (e.g., oxygen levels, trophic status, etc; Kroeze et al., 2008; Solidoro et al. 2005), simpler models may be adequate to serve as functional descriptions of ecosystem services (Barbier, 2008; Russo and Kareiva, 2009) or first-order responses to environmental change (Rahmstorf, 2007). Intermediate complexity tools may be sufficient to serve as screening models, and statistical relationships may be adequate to detect changes in flows (Kunzewicz et al 2009), or to establish relationships between specific human activities and coastal impacts (Howarth et al., 1996). However, examples of coastal waters in which -eomplicated" models fail to address the scope of the problem are increasingly common; the Baltic Sea is one example of a complex system subject to changes in terrestrial nutrient loads (Humborg et al., 2007), abrupt transitions (i.e. apparent regime shifts) in its biogeochemical cycles and oxygen conditions (Vahtera et al., 2007; Savchuk et al., 2008) and in food web structure (Osterblom et al., 2006). Its governance is further complicated by international boundaries and multiple, hierarchical management bodies with a conventional steady-state perspective of the relationship between loading and ecosystem response (Österblom et al. 2010). New theories of governance that incorporate ideas of complex adaptive systems may be useful in such cases (Duit and Galaz, 2008).

Datasets used for coastal classification are also scale-dependent. Coastal typologies intended to characterize regional to global-scale variation of ecosystems and their drivers in coastal waters have typically relied on global datasets of half-degree or greater resolution, and have discriminated coastal regions based on static properties of coastal or associated terrestrial or oceanic grid cells. This Aristotelian" approach to coastal typology has limitations (see Appendix 2, supplementary material). It seems increasingly likely that attempting to categorize the controls on eutrophication at local to regional scales will require more highly resolved data in time and space. Duarte et al. (2008) have shown several examples of nonlinear response of eutrophication to nitrogen loading in coastal waters, including hysteresis and apparent shifts in baseline" response, suggesting that a return to previous trophic status (i.e., restoration") may not be possible. However, these phenomena would probably be overlooked if the analyses were performed at a larger scale. Coastal typologies 
that aim to resolve controls on ecosystem responses have different data requirements than those resolving gross regional patterns of climate or land cover. Clearly, there is no sense in trying to characterize complex responses of coastal waters without sufficiently highly resolved datasets to both drive and validate the models. For example, Yamamuro et al. (2006) have described shifts from submerged aquatic vegetation (SAV) to phytoplankton dominance in Japanese coastal lagoons, in one case resulting in a catastrophic loss of the fishery and in another, an increase of commercial mollusk production. Yamamuro and Icely (this volume) describe conflicts in governance at different scales which result in similar problems. What is the appropriate level of model complexity to characterize such behavior? This represents a modeling as well as a data management challenge.

Finally, the revolution in technology that has brought us GIS, satellite-based remote sensing, and the capability to follow tracers and biomarkers through ecosystems has also streamlined trade and transportation in the business world, making it simpler to move and track materials globally. Now that we have entered the Homogecene, it is clear that the same revolution is responsible for the homogenization of culture, the creation of material flows between distant ecosystems, and the associated degradation of the environment. Modern tracking systems, such as those used in business to follow shipments door-to-door, remain unused, or at least underutilized, in research, possibly due to privacy concerns and other legal issues. Do these represent a new class of tools appropriate for addressing the unique problems of environmental impacts of globalization? Cutting edge technologies, including so called -smart dust" (http://en.wikipedia.org/wiki/Smartdust) and other networks of environmental sensors integrated with analytical software (e.g. Harmon et al., 2009; Galaz et al 2010) have the potential for monitoring spatiotemporal change in coastal ecosystems. Beyond research, can they inform coastal decision making and governance? And, if so, at what scale?

\section{Preliminary answers from LOICZ experience in coastal science}

The questions posed above don't have obvious single answers - if they did, they would not be very fundamental questions. In addition, we are equipped with incomplete understanding based on limited knowledge, which changes as time goes on, corresponding to the ongoing dynamic of change in the coastal zone. This is true of most questions related to the science and management of the coastal zone. However, we can propose a few partial answers:

1) How big are coastal ecosystems and why should we care? While there is no single -size" or scale to coastal ecosystems, we know that they are influenced by activities wellbeyond their immediate boundaries. Human activities in their watersheds have degraded coastal ecological communities, increased areas of eutrophication and dead zones, and reduced abundance of fish and shellfish (Bricker et al., 2007). Critical scaling parameters, such as mean residence time and other measures, can provide bases for multidimensional classification of coastal water bodies, inform us as to the sensitivity of a given water body to various loadings, and thus suggest appropriate management action (Bricker et al. 2003; Buddemeier et al 2008; Swaney et al. 2008).

2) Temporal scales of change in coastal waters and watersheds: Can we detect shifting baselines due to economic development and other drivers? This is a tough one. Human memory is tied to its own relatively short time scales, ranging from the duration of the work day, to the length of a political cycle, to the time between human generations. Time delays in societal and political response to (recognized) regime shifts add to those in the cause-effect relations in ecosystem change. Together, these delays pose a particular challenge for the dynamics of societal response which demand new forms of management which account for 
unpredictability of system behavior as well as ambiguity within the society in framing the responses. Without concerted effort to document change in the environment, gradual degradation escapes our notice, as can the gradual, cumulative impacts which can lead to relatively swift transitions in ecological communities (references). This is why monitoring our coastal waters and their watersheds is of paramount importance. Collecting, curating, and synthesizing monitoring data, and analyzing it with the new insights and novel techniques that science continually provides us, is essential to preserving the quality of coastal environments. Establishing common, accessible datasets for general use (such as those developed by the FAO), and developing accessible tools to analyze data is a start. We must share our results with our peers and students, but also with the coastal governance community, as clearly, straightforwardly and with as little bias as possible. As data-collecting technologies proliferate, we must continue to develop new ways of assimilating, interpreting and visualizing the data, including illustrative models and material budget methods, GIS, coastal typologies, and other methods of synthesizing information, so that it is informative for stakeholders, educators and decision makers. In addition, different modes of communication and dialogue between scientists, policy makers and the public need to form part of the evaluation of shifting baselines in order to include societal valuation and perception of the detected changes.

3) Are footprints more important than boundaries? Because of modern technologies, we have made the world a smaller place. Prior to the industrial revolution, the long-distance transport of materials associated with trade and other human activities was a negligible component of coastal material cycling. Today, footprints" matter as much as the boundaries on a map which define coastal water bodies and their watersheds because they represent the dominant role of human activities in biogeochemical cycling, and we will have to recognize the spatial and temporal scales at which decisions are made that influence footprints. Global decisions (e.g. at the WTO) can create local impacts on footprints at many locations. Therefore, both boundaries and footprints are important for planning and management. More efforts must be made to develop global datasets at finer resolution, e.g. better than countrywide totals or averages, or half-degree grid cells), and developed for natural boundaries (watersheds, water bodies) rather than political or administrative ones. This is especially crucial for understanding watershed interactions with coastal waters. For the practical management of nutrient loads to coastal waters, relatively simple nutrient accounting methods, such as the Net Anthropogenic Nitrogen Input (NANI) methodology (Hong et al. 2011; Boyer et al. 2002) can estimate the magnitudes of net inputs to coastal watersheds and show the relative importance of local versus distant sources. On the governance side, careful analysis of decision making -actors" and the scales at which they operate requires integrated assessments and a range of methodologies and tools from both natural and social sciences. A global example of an integrated assessment is the Millennium Ecosystem Assessment (www.millenniumassessment.org); a regional example is the Coastal Futures project, which examined impacts of offshore wind farms in the German North Sea, including perceptions of the local population, effects on regional economic development and impacts on ecosystem services (Lange et al. 2010). Such assessments rely on GIS-based tools to assess physical characteristics as well as actor-oriented analytical frameworks used in political science (e.g. Scharpf 2000).

4) What makes a decision big? It is fairly clear that the joint impact of small, individual decisions can have as much or more impact on coastal waters than targe" executive decisions made by those charged with coastal governance, though the difficulty of assigning individual responsibility to the many decisions that can collectively amplify into environmental catastrophe is the root of what Hardin called the tragedy of the commons". Attempts by governing bodies to provide structure and accountability to decision making over the range of 
issues affecting coastal regions are fraught with pitfalls and limitations, as discussed above, though there have been some partial successes in grappling with multiple scales of coastal governance. An example is the Resource Management Act (RMA) in New Zealand. The RMA has been deemed, to some extent, a success both nationally and internationally (http://en.wikipedia.org/wiki/Resource_Management_Act_1991). The Act established one single framework in place of separate frameworks divided between different agencies and sectors (e.g., land use, forestry, pollution, water, etc), and was the first national scale statutory planning strategy to adopt sustainability as a core principle, and -sustainable management" as the basis of regulations. The RMA is based on the concept that decisions made locally about a proposed activity are to be made on basis of effects, putting forward the expectation that science-based knowledge be applied to management issues. Unfortunately, the RMA has had failures, including in the area of water quality, which has continued to degrade in New Zealand during the recent period of land development. This appears to be rooted in the inability of regional bodies to prepare and implement standards consistent with the aims of the Act in the face of development. For other environmental issues (e.g., aquaculture) the Act has been more successful. Overall, the Act has provided a unified framework for local bodies to work toward, and some progress has been evident. Such attempts at coordinated decision making over local, regional and global levels (Olsen et al, this volume) represent the best hope for sustainable governance of the coastal zone.

5) Scales of complexity in coastal waters: the simple, the complicated or the complex? Scale matters in coastal waters, for a variety of reasons, as we have seen. We also need to communicate this to those who manage the waters and mediate between stakeholders, and to help provide them with methods to manage appropriately to the scales of the problem at hand on a case by case basis. We may be aided in management by new sensor technologies and monitoring networks for coastal environments, but we also must learn to live with uncertainty in decision making and develop governance systems that are flexible and quickly adaptable in the light of new insights or observations of unintended changes in systems (e.g. through monitoring). We need to recognize that coastal governance has scale issues of its own, and that constraints imposed by institutions at various scales are part of the problem. An awareness of the issues of scale is a first step towards avoiding simplistic - $\rightarrow$ ff the shelf" solutions to complex problems. Transdisciplinary approaches incorporating natural and social sciences within integrated problem assessments may improve understanding of problems (including interaction between scales), that might be help decision makers frame solutions to complex multiscale problems.

\section{Acknowledgements}

Thanks to Karin Limburg, Stephen Olsen, and Alice Newton for comments on and contributions to versions of this manuscript. DPS thanks Bill Dennison, Lawrence Mee, Alice Newton, Stephen Olsen, and Nancy Rabalais for lively discussions during an interesting week in Zavial, Portugal, which saw the genesis of this paper; the interactions between the LOICZ Dahlem-type workshop participants in Oslo, Norway brought this paper to fruition. Some of the concepts discussed above have been strongly influenced by discussions and interactions with Bob Howarth and Gilles Billen.

\section{References}

Alheit, J., Hagen, E., 1997. Long-term climate forcing of European herring and sardine populations. Fisheries Oceanography 6(2), 130-139.

Alheit J., Mollmann C., Dutz, J., Kornilovs G., Loewe P., Mohrholz V., Wasmund N., 2005. Synchronous ecological regime shifts in the central Baltic and the North Sea in the late 1980s. ICES Journal of Marine Science 62(7), 1205-1215. 
Barbier, E.B., Koch, E. W., Silliman, B. R., Hacker, S. D., Wolanski, E., Primavera, J., Granek, E. F., Polasky, S., Aswani, S., Cramer, L. A., Stoms, D. M., Kennedy, C. J., Bael, D., Kappel, C. V., Perillo, G. M. E., Reed, D. J., 2008. Coastal Ecosystem-Based Management with Nonlinear Ecological Functions and Values. Science 319, 321-323.

Berkes, F., Hughes, T. P., Steneck, R. S., Wilson, J. A., Bellwood, D. R., Crona, B., Folke, C., Gunderson, L. H., Leslie, H. M., Norberg, J., Nyström, M., Olsson, P., Österblom, H., Scheffer, M., Worm, B., 2006. Globalization, Roving Bandits, and Marine Resources. Science 311, 1557-1558.

Billé, R., 2006. Integrated Coastal Zone Management: four entrenched illusions. http://sapiens.revues.org/index198.html Accessed March 30, 2011

Billen G, Garnier, J., Némery, J., Sebilo, M., Sferratore, A., Barles, S., Benoit, P., Benoit, A., 2007. A long term view of nutrient transfers through the Seine river continuum. Science of the Total Environment 275, 80-97.

Billen, G., Barles, S. Garnier, J., Rouillard, J., Benoit, P., 2009. The food-print of Paris: longterm reconstruction of the nitrogen flows imported into the city from its rural hinterland. Regional Environmental Change 9, 13-24.

Bindoff, N.L., Willebrand, J., Artale, V., Cazenave, A., Gregory, J., Gulev, S., Hanawa, K., Le Quéré, C., Levitus, S., Nojiri, Y., Shum, C.K., Talley, L.D., Unnikrishnan, A., 2007. Observations: Oceanic Climate Change and Sea Level. In: Solomon, S., Qin, D., Manning, M., Chen, Z., Marquis, M., Averyt, K.B., Tignor, M., Miller, H.L., (Eds.). Climate Change 2007: The Physical Science Basis. Contribution of Working Group I to the Fourth Assessment Report of the Intergovernmental Panel on Climate Change. Cambridge University Press, Cambridge, UK and New York, NY, USA

Boyer, E. W., Goodale, C. L., Jaworski, N. A., Howarth, R. W., 2002. Anthropogenic nitrogen sources and relationships to riverine nitrogen export in the northeastern USA. Biogeochemistry 57/58, 137-169

Boynton, W.R, Hagy, J.D., Breitburg, D.L., 2001. Issues of scale in land-margin ecosystems. In: Gardner, R.H., Kemp, W.M., Kennedy, V.S., Petersen, J.E. (Eds.), Scaling Relations in Experimental Ecology. Columbia University Press, NY. (Complexity in Ecological Systems Series) pp 299-330.

Bricker, S.B., Ferreira, J.G., Sima, T., 2003. An Integrated Methodology for Assessment of Estuarine Trophic Status. Ecological Modelling 169(1), 39-60.

Bricker, S., Longstaff, B., Dennison, W., Jones, A., Boicourt, K., Wicks, C., Woerner, J., 2007. Effects of Nutrient Enrichment in the Nation's Estuaries: A Decade of Change, National Estuarine Eutrophication Assessment Update. NOAA Coastal Ocean Program Decision Analysis Series No. 26. National Centers for Coastal Ocean Science, Silver Spring, MD. 322 pp.

Brock, W. A., Carpenter, S. R., 2006. Variance as a leading indicator of regime shift in ecosystem services. Ecology and Society 11:9. http://www.ecologyandsociety.org/vol11/iss2/art9/ Accessed March 31, 2011.

Brush, G. 2008. Historical land use, nitrogen, and coastal eutrophication: A paleoecological perspective. Estuaries and Coasts DOI 10.1007/s12237-008-9106-Z

Buddemeier, R.W., Smith, S.V., Swaney, D.P., Crossland, C.J., Maxwell, B.A., 2008. Coastal typology: An integrative -neutral" technique for coastal zone characterization and analysis. Estuarine, Coastal and Shelf Science. 77, 197-205.

Carlton, J.T., 1999. The scale and ecological consequences of biological invasions in the world's oceans. In: Sandulund, O., Schei, P., Viken,A. (Eds.), Invasive Species and 
Biodiversity Management. eds. Kulwer Academic Publishers. Dordrecht, Netherlands. pp.195-212

Carlton, J. T., 2001. Introduced species in U.S. coastal waters: environmental impacts and management priorities. Pew Oceans Commission, Arlington, Virginia, USA.

http://www.pewtrusts.org/uploadedFiles/wwwpewtrustsorg/Reports/Protecting_ocean_life/ env_oceans species.pdf Accessed March 31, 2011

Cheung, W.W.L., V. W. Y. Lam, J. L. Sarmiento, K. Kearney, R. Watson, and D. Pauly. 2009. Projecting global marine biodiversity impacts under climate change scenarios. Fish and Fisheries 10(3), 235-251.

Cossarini C., Libralato S., Salon S., Giorgi F., Solidoro C., 2008. A downscaling experiment for the lagoon of Venice, part II. Testing potential impacts of changes in precipitation temporal patterns on biogeochemical properties. Climate Research 38, 43-59..

Crossland, C.J., Kremer, H.H., Lindeboom, H.J., Marshall Crossland, J.I., Le Tissier, M.D.A. (Eds.), 2005. Coastal Fluxes in the Anthropocene; The Land-Ocean Interactions in the Coastal Zone Project of the International Geosphere-Biosphere Programme. Springer, Berlin 231pp

deYoung, B., Barange, M., Beaugrand, G., Harris, R., Perry, R. I., Scheffer, M., Werner, F., 2008. Regime shifts in marine ecosystems: detection, prediction and management. Trends in Ecology and Evolution 23 (7), 402 - 409)

Duarte, C., Conley, D. J., Carstensen, J., Sánchez-Camacho, M., 2008. Return to Neverland: Shifting baselines affect eutrophication restoration targets. Estuaries and Coasts DOI $10.1007 / \mathrm{s} 12237-008-9111-2$

Duit, A., Galaz, V., 2008. Governance and complexity-emerging issues for governance theory. Governance: An International Journal of Policy, Administration, and Institutions 21(3), 311-335.

Ehrlich, P.R., Kennedy, D., 2005. Millenium assessment of human behavior. Science 309, 562-563.

Ericson, J.P., Vorosmarty, C.J., Dingman, S.L., Ward, L.G., Meybeck, M., 2006. Effective sea-level rise and deltas: Causes of change and human dimension implications. Global and Planetary Change 50, 63-82.

Fagherazzi, S., Carniello, L., D’Alpaos, L., Defina, A., 2006. Critical bifurcation of shallow microtidal landforms in tidal flats and saltmarshes. Proceedings of the National Academy of Sciences 103, 8337-8341.

Folke, C., Carpenter, S., Walker, B., Scheffer, M., Elmqvist, B., Gunderson, L., Holling, C.S., 2004. Regime shifts, resilience, and biodiversity in ecosystem management. Annual Review of Ecology, Evolution and Systematics 35, 557-81.

Galaz, V., Crona, B., Daw, T., Bodin, Ö., Nyström,M., Olsson,P., 2010. Can web crawlers revolutionize ecological monitoring? Frontiers in Ecology and the Environment 8(2), 99104

Gertner, J., 2009. Why isn't the brain green? The New York Times Magazine, Sunday, April 19, 2009. pp36-43. http://www.nytimes.com/2009/04/19/magazine/19Sciencet.html?_r=1\&hpw Accessed March 30, 2011.

Giesen, W., Wulffraat, S., Zieren, M. Scholten, L., 2006. Mangrove Guidebook for Southeast Asia. FAO and Wetlands International. (http://www.fao.org/docrep/010/ag132e/ag132e00.htm). Accessed March 30, 2011.

Glouberman, S., Zimmerman, B., 2002. Complicated and complex systems: What would successful reform for medicare look like? Commission on the future of health care Canada. Discussion paper no. 8.30 pp. 
Haas, P.M., 1989. Do regimes matter? Epistemic communities and Mediterranean pollution. International Organization. The MIT Press Summer, 1989. 43(3), 377-403.

Harmon, T.C., Villamizar Amaya, S., Butler, C. A., Pai, H., Barnes, P., Fisher, J., Silva, F., Stathopoulos, T., Kaiser, W., 2009. Closing the loop on groundwater-surface water interactions, river hydrodynamics, and metabolism on the San Joaquin River Basin. UCLA: Center for Embedded Network Sensing. http://escholarship.org/uc/item/40d148r2, Accessed February 2, 2010.

Hoa, L.T.V., Nhan, N. H., Wolanski, E., Cong, T. T., Shigeko, H., 2007. The combined impact on the flooding in Vietnam's Mekong River delta of local man-made structures, sea level rise, and dams upstream in the river catchment. Estuarine, Coastal and Shelf Science 71, 110-116.

Hong, B. and D.P. Swaney. 2009. Net Anthropogenic Nitrogen Inputs (NANI) Toolbox Documentation. 39 pp. http://www.eeb.cornell.edu/biogeo/nanc/nani/NANI_Calculator_Toolbox_Documentation.pdf Accessed March 18, 2011

Hong, B., Swaney, D.P., Howarth, R. W., 2011. A toolbox for calculating net anthropogenic nitrogen inputs (NANI). Environmental Modelling and Software 26, 623-633.

Houde, E.D., Rutherford, E.S., 1993. Recent trends in estuarine fisheries: Predictions of fish production and yield. Estuaries 16, 161-176.

Howarth, R.W., Billen, G., Swaney, D. P., Townsend, A., Jaworski, N., Lajtha, K., Downing, J. A., Elmgren, R., Caraco, N., Jordan, T., Berendse, F., Freney, J., Kudeyarov, V., Murdoch, P., Zhu Zhao-liang. 1996. Riverine inputs of nitrogen to the North Atlantic Ocean: Fluxes and human influences. Biogeochemistry 35, 75-139.

Howarth, R. W., Swaney, D.P., Billen, G., Garnier, J., Hong, B., Humborg, C., Johnes, P., Morth, C., Marino, R,. 2011. Nitrogen fluxes from large watershed to coastal ecosystems controlled by net anthropogenic nitrogen inputs and climate. Frontiers in Ecology and Environment. Jn press.

Humborg, C., Pastuszak, M., Aigars, J. Siegmund, H., Mörth, C.-M., Ittekkot, V., 2006. Decreased silica land-sea fluxes through damming in the Baltic Sea catchment significance of particle trapping and hydrological alterations. Biogeochemistry 77, 265281.

Humborg, C., Mörth, C.-M., Sundbom, M., Wulff, F., 2007. Riverine transport of biogenic elements to the Baltic Sea - past and possible future perspectives. Hydrology and Earth System Sciences 11, 1593-1607.

Justic', D., Rabalais, N.N., Turner, R.E., 2002. Modeling the impacts of decadal changes in riverine nutrient fluxes on coastal eutrophication near the Mississippi River delta. Ecological Modeling 152, 33-46.

Kahn, A. E., 1966. The tyranny of small decisions: market failures, imperfections, and the limits of economics. Kvklos 19, 23- 47.

Kannen, A., Gee, K., Licht-Eggert, K., 2008. Managing changes in sea use across scales: North Sea and North Sea coast of Schleswig-Holstein. In: Krishnamurthy, R.R. et al. (Eds.), ICZM - The global challenge. Research Publishing, Chennai, India, pp. 93-108.

Koch, E.W., Barbier, E.B., Silliman, B.R., Reed, D.J., Perillo, G.M.E., Hacker, S.D., Granek, E.F., Primavera, J.H., Muthiga, N., Polasky, S., Halpern, B.S., Kennedy, C.J., Kappel, C.V., Wolanski, E., 2009. Non-linearity in ecosystem services: temporal and spatial variability in coastal protection. Frontiers in Ecology and the Environment 7, 29-37.

Kroeze, C., Middelburg, J., Leemans, R., Escobar-Briones, E., Fennel, W., Glaser, M., Harashima, A., Liu, K. K., Meybeck, M., 2008. Integrating tools to assess changes in semi- 
enclosed marine systems. In: Urban Jr., E. R., Sundby, B., Malanotte-Rizzoli, P., Melillo, Environment (SCOPE) Series Vol. 70. pp77-96.

Kundzewicz, Z.W., Nohara, D., Tong, J., Oki, T., Buda, S., Takeuchi, K., 2009. Discharge of large Asian rivers: observations and projections. Quaternary International doi:10.1016/j.quaint.2009.01.011

Lange, M., Burkhardt, B., Garthe, S., Gee, K., Kannen, A., Lenhart, H., Windhorst, W., 2010. Analyzing Coastal and Marine Changes: Offshore Wind Farming as a Case Study: Zukunft Küste - Coastal Futures Synthesis Report. LOICZ Research \& Studies No. 36. GKSS Research Centre, Geesthacht, Germany. 212 pp.

Levrel, H., 2007. Selecting indicators for the management of biodiversity. Institut Francais de la Biodiversité. Paris. 98 pp.

Li, M., Xu, K., Watanabe, M., Chen, Z., 2007. Long-term variations in dissolved silicate, nitrogen, and phosphorus flux from the Yangtze River into the East China Sea and impacts on estuarine ecosystem. Estuarine, Coastal and Shelf Science 71, 3-12

Limburg, K.E., Waldman, J. R., 2009. Dramatic declines in North Atlantic diadromous fishes. BioScience 59, 955-965.

Lotze, H.K., Lenihan, H. S., Bourque, B. J., Bradbury, R. H., Cooke, R. G., Kay, M. C., Kidwell, S. M., Kirby, M. X., Peterson, C. H., Jackson, J. B. C., 2006. Depletion, degradation, and recovery potential of estuaries and coastal seas. Science 312, 1806-1809.

Luisetti,T., Turner, R. K., Bateman, I. J., Morse-Jones,S., Adams, C., Fonseca, L., 2011. Coastal and marine ecosystem services valuation for policy and management: Managed realignment case studies in England, Ocean and Coastal Management 54(3), 212-224

Marx, S.M., Weber, E. U., Orlove, B. S., Leiserowitz, A., Krantz, D. H., Roncoli, C., Phillips, J., 2007. Communication and mental processes: Experiential and analytic processing of uncertain climate information. Global Environmental Change 17(1), 47-58.

Meijerink, S., Dicke, W., 2008. Shifts in the public-private divide in flood management. International Journal of Water Resources Development. 24, 499-512.

Meijerink, S.V., 2005., Understanding policy stability and change: the interplay of advocacy coalitions and epistemic communities, windows of opportunity and Dutch coastal flooding policy 1945-2003. Journal of European Public Policy 12(6), 1060-1077.

Melaku Canu, D., Solidoro, C., Cossarini, G., Giorgi, F., 2010. Effect of global change on bivalve rearing activity and need of implementation of adaptive management. Climate Research 42, 13-26.

Meybeck, M., 2003. Global analysis of river systems: from Earth system controls to anthropocene syndromes. Phil. Trans. R. Soc. Lond. B. DOI 10.1098/rstb.2003.1379

Mozetič P., Solidoro, C., Cossarini, G., Socal, G., Precali, R., Francé, J., Bianchi, F., De Vittor, C., Smodlaka, N., Fonda Umani, S., 2010 Recent trends towards oligotrophication of the Northern Adriatic: Evidence from chlorophyll a time series. Estuaries and Coasts DOI 10.1007/s12237-009-9191-7

Murawski, S. A., 2007. Ten myths concerning ecosystem approaches to marine resource management. Marine Policy doi:10.1016/j.marpol.2007.03.011

Nixon, S.W., Fulweiler, R. W., Buckley, B. A., Granger, S. L., Nowicki, B. L., Henry, K. M., 2009. The impact of changing climate on phenology, productivity, and benthic-pelagic coupling in Narragansett Bay. Estuarine, Coastal and Shelf Science 82, 1-18

Nixon, S.W., Buckley, B. A., Granger, S. L., Harris, L.A., Oczkowski, A.J., Fulweiler, R. W., Cole, L.W., 2008. Nitrogen and phosphorus inputs to Narragansett Bay: Past, present and 
future. In: Desbonnet, A., Costa-Pierce, B.A. (Eds.), Science for Ecosystem-Based management. Narragansett Bay in the $21^{\text {st }}$ Century. Springer, New York, pp. 101-176.

Odum, W. E., 1982. Environmental degradation and the tyranny of small decisions. BioScience 32, 728-729.

Olmstead, P.S., Tukey, J.W., 1947. A corner test for association. Annals of Mathematical Statistics 18, 495-513.

Osterblom, H., Casini, M., Olsson, O., Bignert, A., 2006. Fish, seabirds and trophic cascades in the Baltic Sea. Marine Ecology Progress Series 323, 233-238.

Österblom, H, Gårdmark, A., Bergström, L., Mueller-Karulis, B., Folke, C., Lindegren, M., Casini, M., Olsson, P., Diekmann, R., Blenckner, T., Humborg, C., Möllmann, C., 2010. Making the ecosystem approach operational-Can regime shifts in ecological-and governance systems facilitate the transition? Marine Policy 34, 1290-1299.

Rahmstorf, S. 2007. A semi-empirical approach to projecting future sea-level rise. Science $315,368-370$.

Restrepo, J. D., Zapata, P., Diaz, J.M., Garzon-Ferreira, J., Garcia, C.B., 2006. Fluvial fluxes into the Caribbean Sea and their impact on coastal ecosystems: The Magdalena River, Colombia. Global and Planetary Change 50, 33-49.

Richmond, R.H., Rongo, T., Golbuu, Y., Victor, S., Idechong, N., Davis, G., Kostka, W., Neth, L., Hamnett, M., and Wolanski, E., 2007. Watersheds and coral reefs: Conservation science, policy and implementation. BioScience 57, 598-607.

Rooney, T.P., Olden, J. D., Leach, M. K., Rogers D. A., 2007. Biotic homogenization and conservation prioritization. Biological Conservation 134, 447-450

Rosenzweig, M.L., 2001. The four questions: what does the introduction of exotic species do to diversity? Evolutionary Ecology Research 3, 361-367.

Russell, M. J., Weller, D.E., Jordan, T.E., Sigwart, K.J. Sullivan, K.J., 2008. Net anthropogenic phosphorus inputs: spatial and temporal variability in the Chesapeake Bay region. Biogeochemistry 88(3), 285-304.

Russo, S., Kareiva, P., 2009. Using science to assign value to nature. Frontiers in Ecology and the Environment 7(1), 3.

Savchuk, O.P., Wulff, F., Hille, S., Humborg, C., Pollehne, F., 2008. The Baltic Sea a century ago - a reconstruction from model simulations, verified by observations. Journal of Marine Systems 74, 485-494.

Scharpf, F., 2000. Interaktionsformen: Akteurzentrierter Institutionalismus in der Politikforschung. VS Verlag für Sozialwissenschaften, Wiesbaden. 474 pp.

Schlüter, M.H., Merico, A., Wiltshire, K. H., Greve, W., von Storch, H., 2008. A statistical analysis of climate variability and ecosystem response in the German Bight. Ocean Dynamics 58, 169-186

Silvert, W., Smith, W. R., 1981. The response of ecosystems to external perturbations. Mathaematical Biosciences 55, 279-306.

Silvert, W., 1983. Amplification of environmental fluctuations by marine ecosystems. Oceanol. Acta. Proceedings of the 17th European Marine Biological Symposium, pp. 183186.

Silvert, W., Crawford, R. J. M., 1988. The periodic replacement of one fish stock by another. Proceedings of the International Symposium on Long Term Changes in Marine Fish Populations, Vigo, Spain, Nov. 1986., pp. 161-180.

Silvert, W. 2001. Modelling as a discipline. Int. J. General Systems 30, 261-282. 
Smith, S. V., Buddemeier, R. W., Wulff, F., Swaney, D. P., 2005. C, N, P fluxes in the coastal zone. In: Crossland, C.J.; Kremer, H.H.; Lindeboom, H.J.; Marshall Crossland, J.I.; Le Tissier, M.D.A. (eds). Coastal Fluxes in the Anthropocene. The Land-Ocean Interactions in the Coastal Zone Project of the International Geosphere-Biosphere Programme. Springer-Verlag, Berlin Heidelberg, pp. 95-143.

Sokal, R. R., Rohlf, F. J., 1995. Biometry: the principles and practice of statistics in biological research. 3rd edition. W. H. Freeman and Co, New York. 887 pp.

Solidoro C., Pastres R., Cossarini G., 2005. Nitrogen and plankton dynamics in the lagoon of Venice. Ecological Modelling 184, 103-124.

Solidoro C., Cossarini, G., Libralato, S., Salon, S., 2010a. Remarks on the redefinition of system boundaries and model parameterization for downscaling experiments. Progress in Oceanography 84, 134-137 doi:10.1016/j.pocean.2009.09.017

Solidoro C., Bandelj, V., Aubry Bernardi, F., Camatti, E., Ciavatta, S., Cossarini, G., Facca, C., Franzoi, P., Libralato, S., Melaku Canu, D., Pastres, R., Pranovi, F., Raicevich, S., Socal, G., Sfriso, A., Sigovini, M., Tagliapietra, D., Torricelli, P., 2010b. Response of Venice Lagoon ecosystem to natural and anthropogenic pressures over the last 50 years. In: Kennish, M.H.K., Paerl, H. (Eds.), Coastal Lagoons: Critical habitats of environmental change. CRC Press, Boca Raton, FL. Pp 483-512.

Sterman, J.D., 2002. All models are wrong: reflections on becoming a systems scientist. System Dynamics Review 18(4), 501-531.

Stockner, J.G., Ryden, E., Hyenstrand, P., 2000. Cultural oligotrophication: Causes and consequences to fisheries resources. Fisheries 25, 7-14.

Stojanovic, T., Barker, N., 2008. Improving governance through local coastal partnerships in the UK. The Geographical Journal 174, 344-360.

Swaney, D.P., Smith, S.V., Wulff, F., In Press. The LOICZ biogeochemical modeling protocol and its application to estuarine ecosystems. In: Baird, D and A. Mehta (Eds.), Treatise on Estuarine and Coastal Science, Vol. 9, Elsevier.

Swaney, D.P., Scavia, D., Howarth, R.W., Marino, R.M., 2008. Estuarine classification and response to nitrogen loading: insights from simple ecological models. Estuarine, Coastal and Shelf Science 77, 253-263.

Swaney, D.P., Limburg, K. E., Stainbrook, K. M., 2006. Some historical changes in the patterns of population and land use in the Hudson River watershed. American Fisheries Society Symposium 51, 75-112.

Syvitski, J.P.M., Kettner, A.J., Overeem, I., Hutton, E. W. H., Hannon, M. T., Brakenridge, G. R., Day, J., Vörosmarty, C., Saito, Y., Giosan, L., Nicholls, R. J., 2009. Sinking deltas due to human activities. Nature Geoscience 2, 681-686.

Tett, P., Wilson, H., 2000. From biogeochemical to ecological models of marine microplankton. Journal of Marine Systems 25, 431-446.

Tompkins, E.L., Few, R., Brown, K., 2008. Scenario-based stakeholder engagement: Incorporating stakeholders preferences into coastal planning for climate change. Journal of Environmental Management 88, 1580-1592.

Turner, R.E., Rabalais, N.N., 2003. Linking landscape and water quality in the Mississippi River Basin for 200 years. Bioscience 53, 563-572.

UNEP., 2006. Marine and Coastal ecosystems and Human Well-being. A synthesis report based on the findings of the Millennium Ecosystem Assessment. UN Environment Programme, Nairobi, Kenya.

Vahtera, E., Conley, D.J., Gustafsson, B.G., Kuosa, H., Pitkänen, H., Savchuk, O.P., Tamminen, T., Viitasalo, M., Voss, M., Wasmund, N., Wulff, F., 2007. Internal ecosystem 
feedbacks enhance nitrogen-fixing cyanobacteria blooms and complicate management in the Baltic Sea. Ambio 36(2-3), 186-194.

Vörösmarty, C.J., Sharma, K. P., Fekete, B. M., Copeland, A. H., Holden, J., Marble, J., Lough, J. A., 1997. The storage and aging of continental runoff in large reservoir systems of the world. Ambio 26(4), 210-219

Wackernagel, M., Rees, W. E., 1996. Our Ecological Foot-print: Reducing Human Impact on the Earth. New Society Publishers, Gabriola Island, British Columbia, Canada, 176 pp.

Wallace, J.M., Gutzler, D.S., 1981. Teleconnections in the geopotential height field during the northern hemisphere winter. Monthly Weather Review 109, 784-812.

Wedden, W.P., 1929. How great cities are fed. D.C. Heath, Boston. 285 pp.

Wiedmann, T., Minx, J., 2008. A definition of 'carbon footprint'. In: Pertsova, C. C. (Ed.), Ecological Economics Research TrendsNova Science Publishers, Hauppauge NY, USA, pp. 1-11,

Wolanski, E., 2006. Increasing trade and urbanization of the Asia Pacific coast. In: E. Wolanski (Ed.). The Environment in Asia Pacific Harbours. Springer. pp.1-13.

Wolanski, E., 2007. Estuarine Ecohydrology. Elsevier. 169 pp.

Woodroffe, C.D., Nicholls, R. J., Saito, Y., Chen, Z., Goodbred, S. L., 2006. Landscape variability and the response of asian megadeltas to environmental change. In: Harvey, N. (Ed.), Global Change and Integrated Coastal Management, Springer, pp 277-314.

Xu, K., Chen, Z., Zhao, Y., Wang, Z., Zhang, J., Hayashi, S., Murakami, S., Watanabe, M., 2005. Simulated sediment flux during 1998 big-flood of the Yangtze (Changjiang) River, China. Journal of Hydrology 313, 221-233.

Xue, P., Chen, C., Ding, P., Beardsley, R. C., Lin, H., Ge, J., Kong, Y., 2009. Saltwater intrusion into the Changjiang River: A model-guided mechanism study. Journal of Geophysical Research 114:doi:10.1029/2008JC004831

Yamamuro, M., Hiratsuka, J.-I., Ishitobi, Y., Hosokawa, S., Nakamura, Y., 2006. Ecosystem shift resulting from loss of eelgrass and other submerged aquatic vegetation in two estuarine lagoons, Lake Nakaumi and Lake Shinji, Japan. Journal of Oceanography 62, 551-558.

Zahariadis, N., 2007. The multiple streams framework: structure, limitations, prospects. In: Sabatier, P.A. (Ed): Theories of the Policy Process, Westview Press, pp 65-92. 


\section{List of figures, with captions}

Figure 1: Relationships between time and space scales for a) physical factors, b) biological factors, c) governance and d) drivers of ecosystem change in coastal waters and watersheds.

Figure 2: Apparent net ecosystem production for LOICZ budget sites as a function of system area (log-log plots). a) Net heterotrophic systems (p-r $<0$; absolute value used). b) Net autotrophic systems (p-r $>0$ ). (Smith et al. 2005).

Figure 3: (a) The Chesapeake watershed at different historical periods: pre-Colonial up to 1650 , showing a forested landscape with a large beaver population; early Colonial, when $\sim 40 \%$ of the land was deforested for agriculture; intensive agriculture, when up to $80 \%$ of the land was under cultivation; and urbanization, when about half of the watershed is in forest and urban and suburban centers characterize some parts of the watershed. (b) The increase in the human population. (c) The historical record of land use. (d) Sales of fertilizer in the Chesapeake watershed. (e) Historical record of nitrogen fluxes into the Potomac River. (f) The historical record of the crab and oyster harvest. (g) Pollen representation of land use in the upper estuary. (h) Paleoecological record of sedimentation rates in the upper estuary. (i) Pollen profile showing a gradual increase in dry taxa after colonization. (j) Nitrogen influx into the Chesapeake Bay. (k) The change in the ratio of planktonic to benthic diatom species in the central mesohaline section of the estuary (Brush, 2008)

Figure 4. Historical and future estimates of sea level change, relative to the present, from the 2007 IPCC report (Bindoff et al. 2007)

Figure 5. Winter season averages of North Atlantic Oscillation Index (NAO) and average sea surface temperatures in the North Sea and Baltic Sea. (Alheit et al. 2005).

Figure 6: Terrestrial net primary production of agricultural and forested land (Autotrophy) (a), and total heterotrophic consumption by human and domestic animals and by forest communities (Heterotrophy) (b) in the Seine watershed. Distribution of the autotrophy: heterotrophy ratio (c): Yellow areas are in approximate equilibrium; green areas are autotrophic, orange or red areas are heterotrophic (Billen et al 2007). The Paris metropolitan area is highlighted in red, indicating a high net consumption of nutrients, with implications for the downstream waters of the Seine.

Figure 7: Net anthropogenic nitrogen input (kg-N/ $\left.\mathrm{km}^{2} / \mathrm{yr}\right)$ in a) northeastern US watersheds and b) Hudson River watershed subbasins. The larger scale patterns on driven by latitudinal gradients of population, agriculture, and atmospheric N deposition. Within the Hudson catchment, the intense levels of anthropogenic nitrogen input on the coast correspond to the large food imports of the New York City metropolitan area and local elevated N deposition associated with high automobile densities. (Hong and Swaney 2009)

Figure 8: The range of scale of institutional involvement at for coastal systems of various size scales. The paradox of scale" is that the smaller the geographic size of the coastal ecosystem, the more entities that —ontribute" to its governance (i.e. the largest regions are governed only by international bodies; the smallest by local to international entities) (Murawski 2007). 

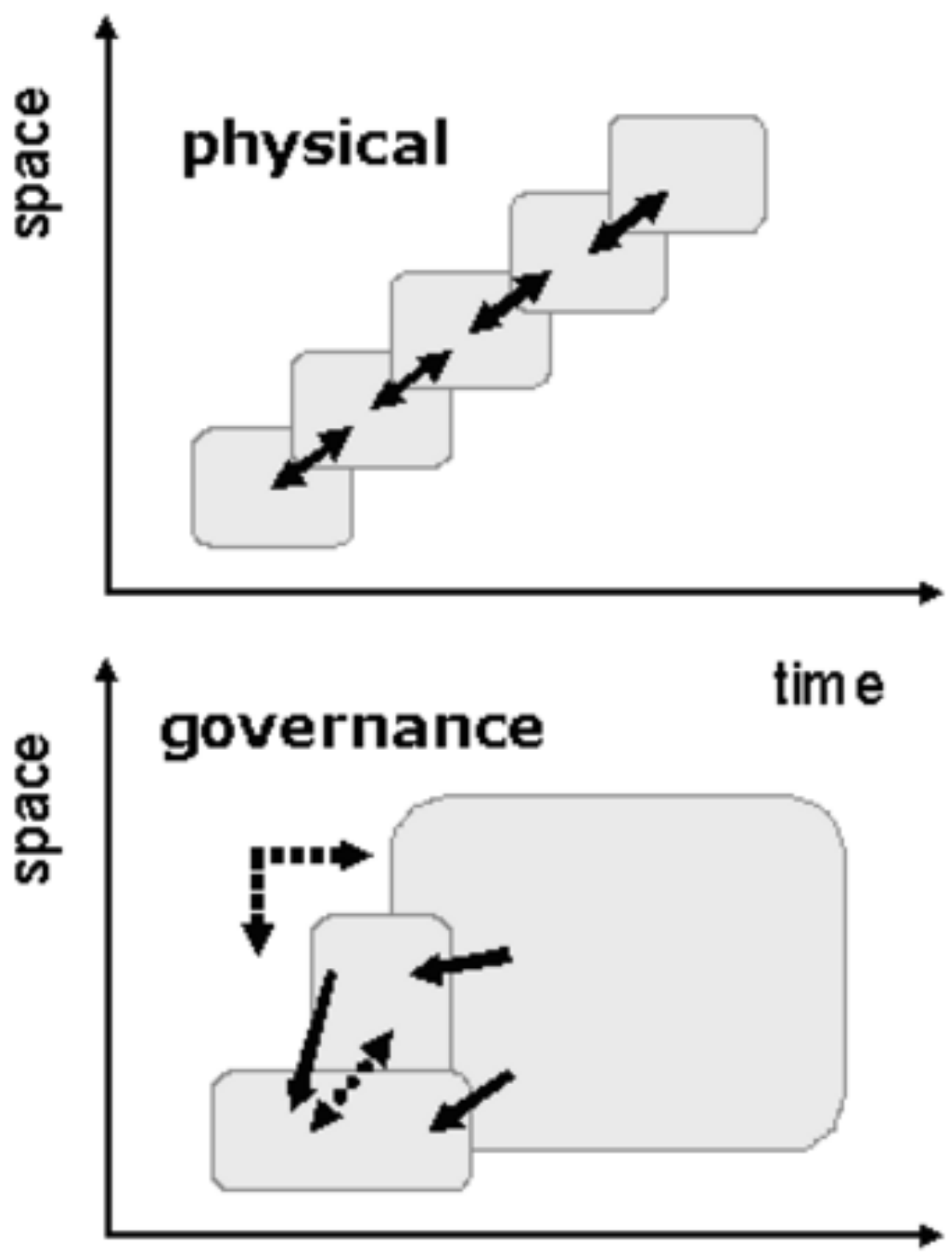

time
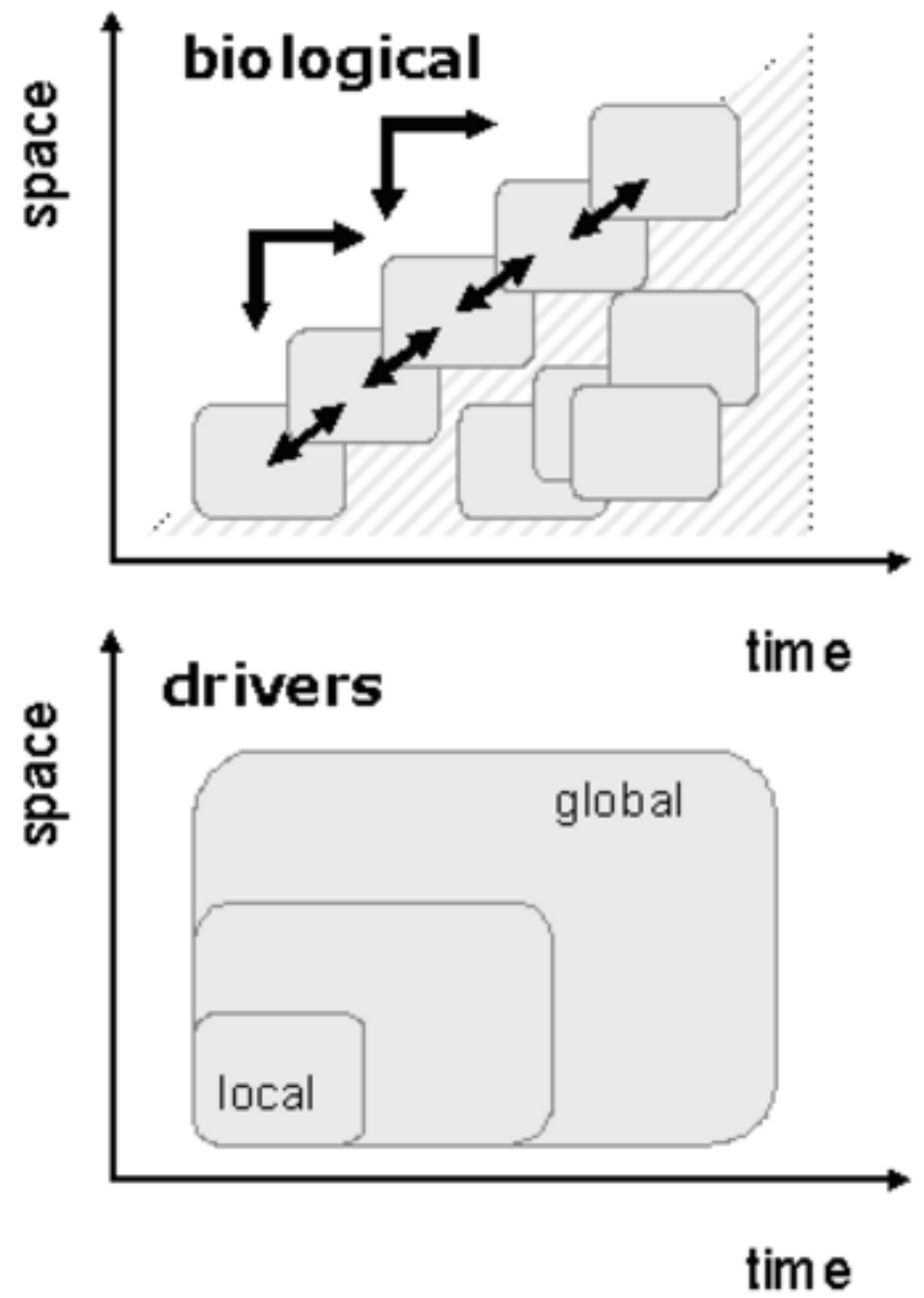

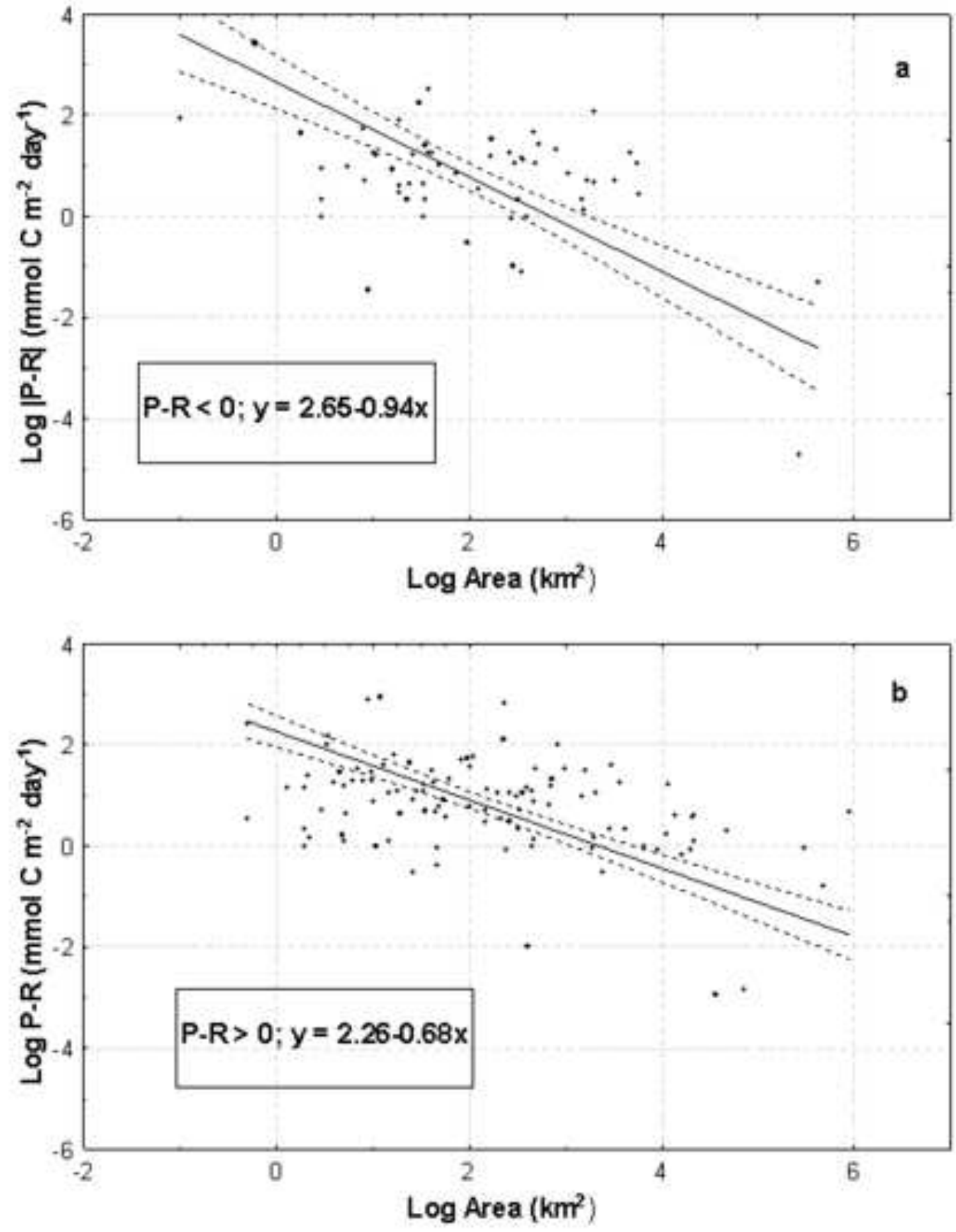
Figure(s) 3
Click here to download high resolution image

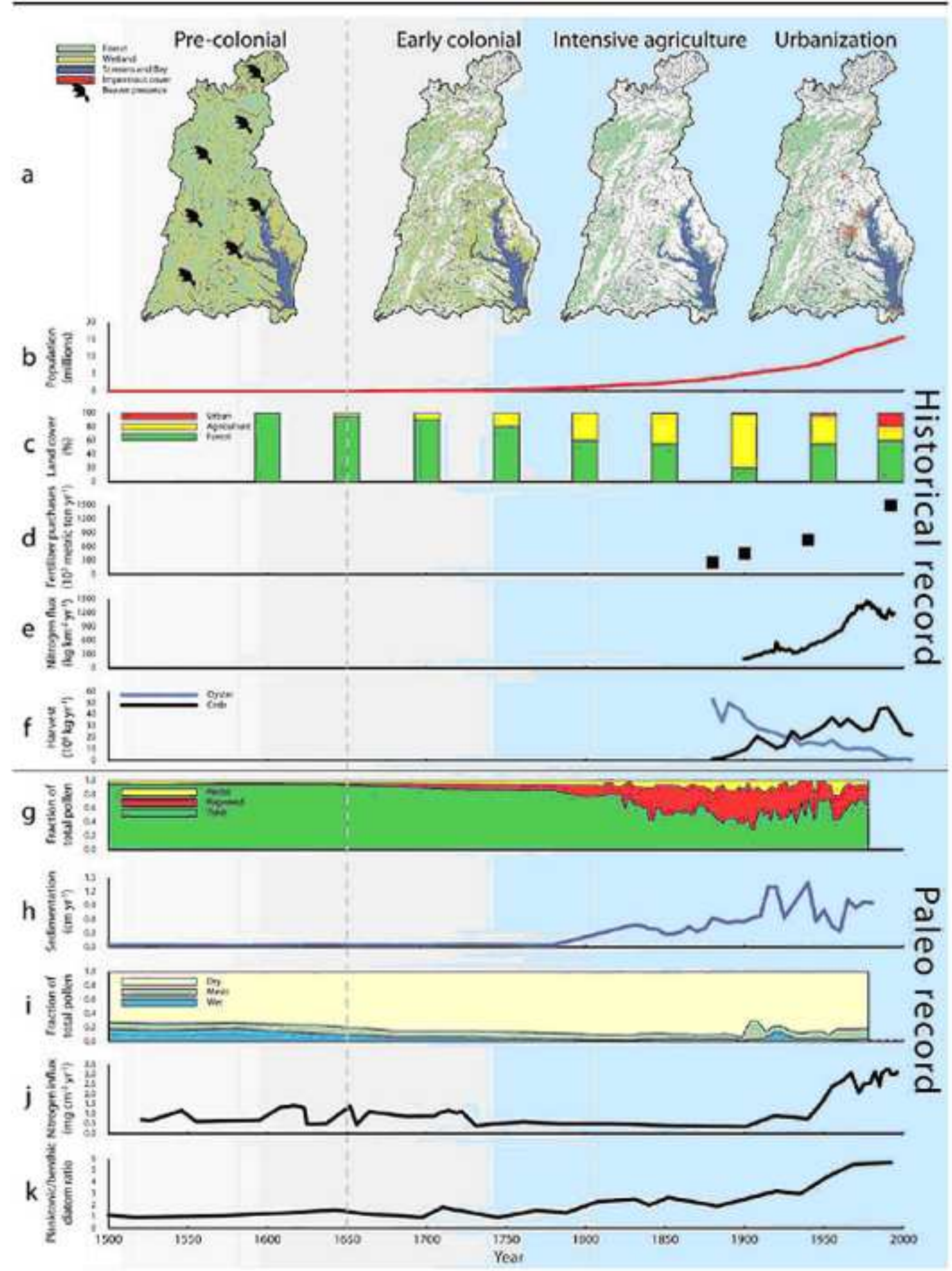




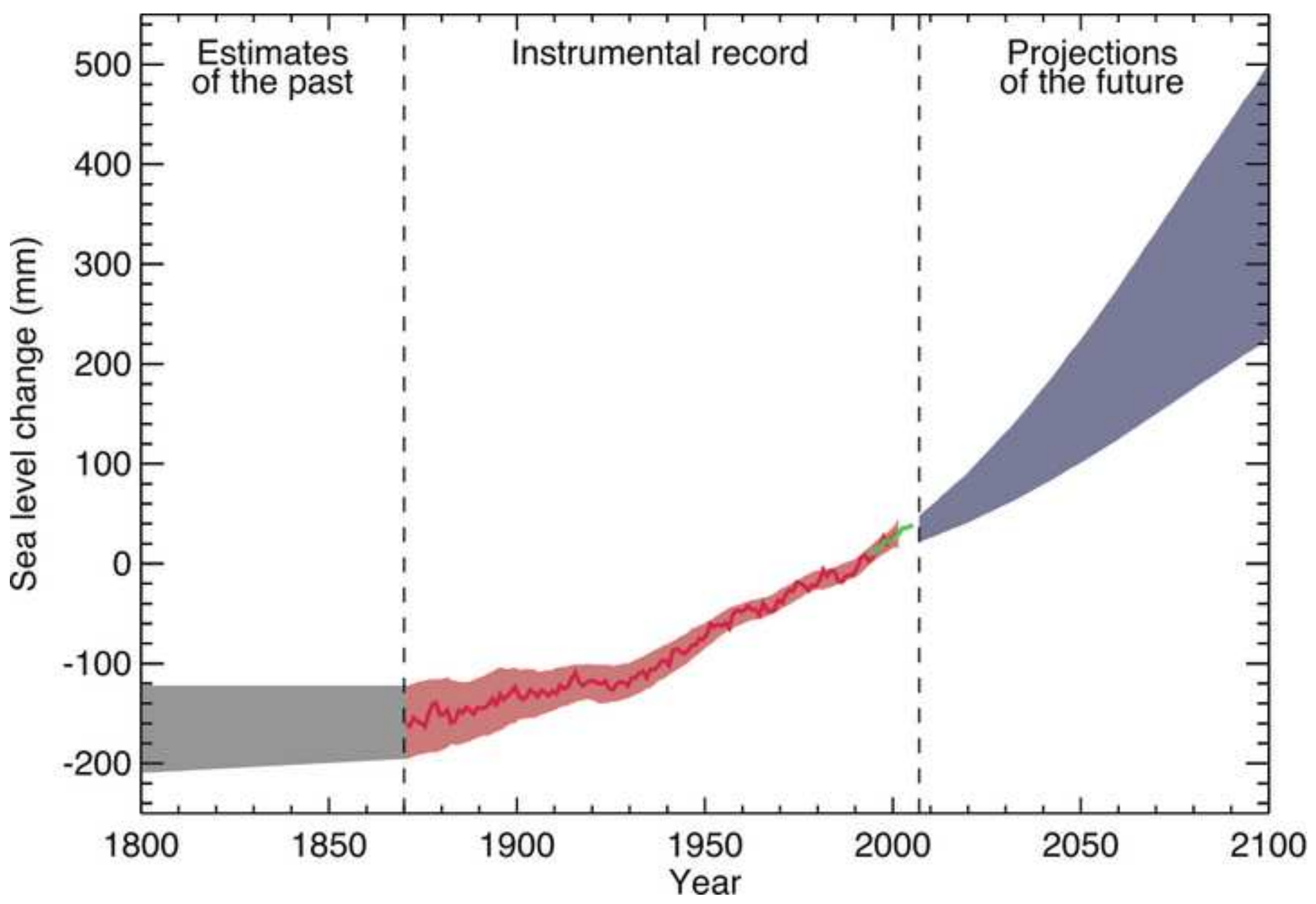




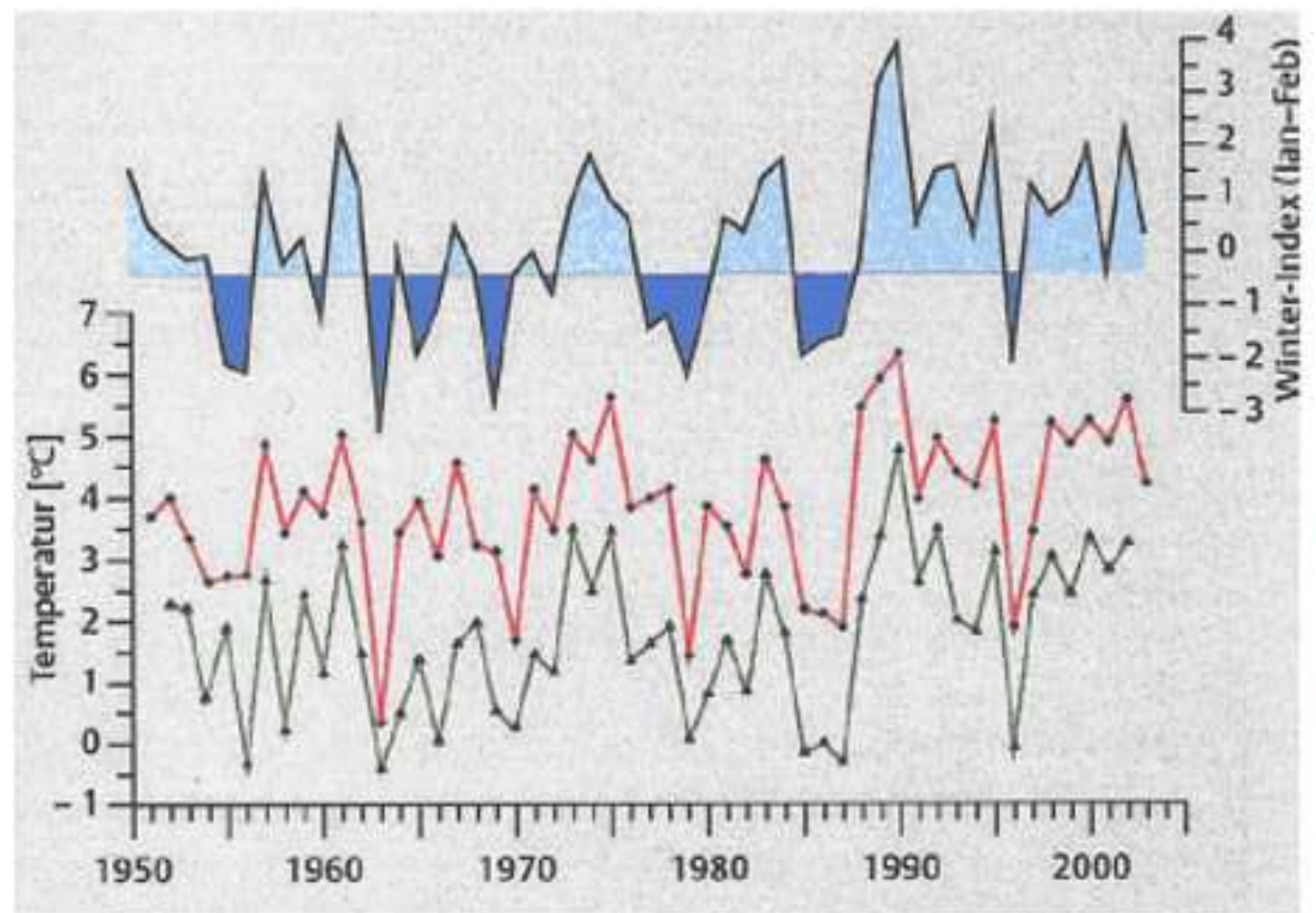

Water Temp. North Sea

Water Temp. Baltic Sea

NAO Index 
Figure(s) 6

Click here to download high resolution image

a.

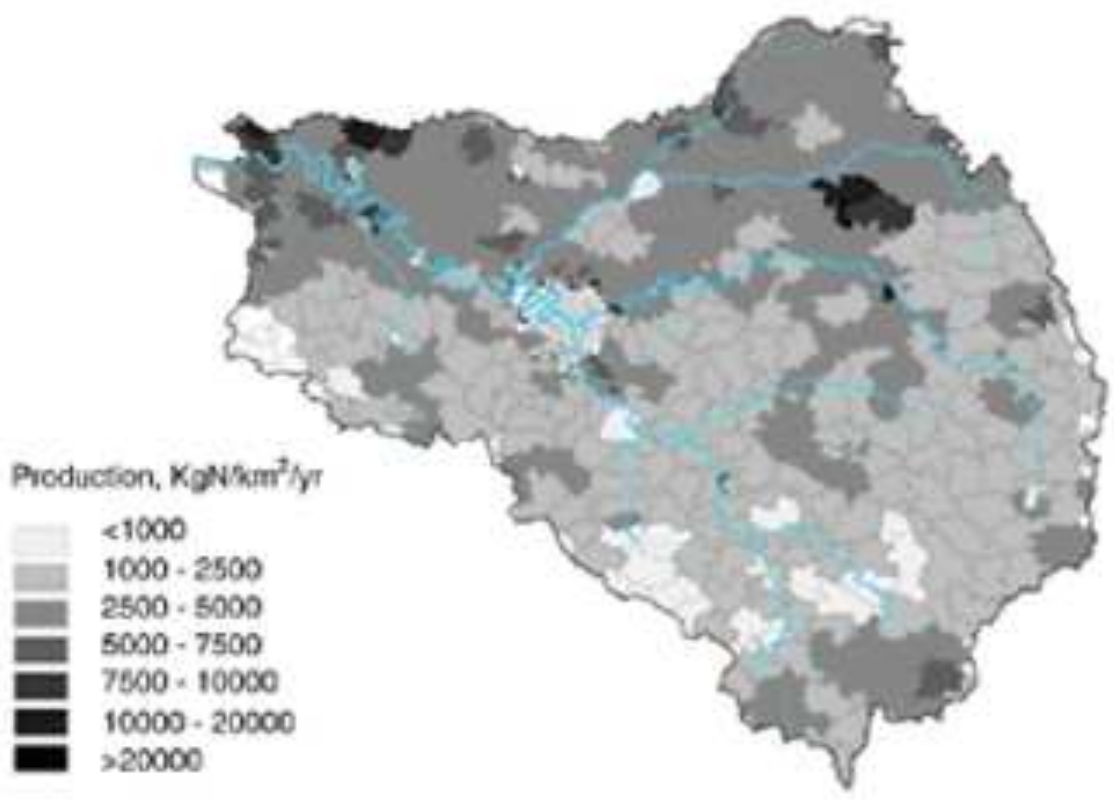

b.

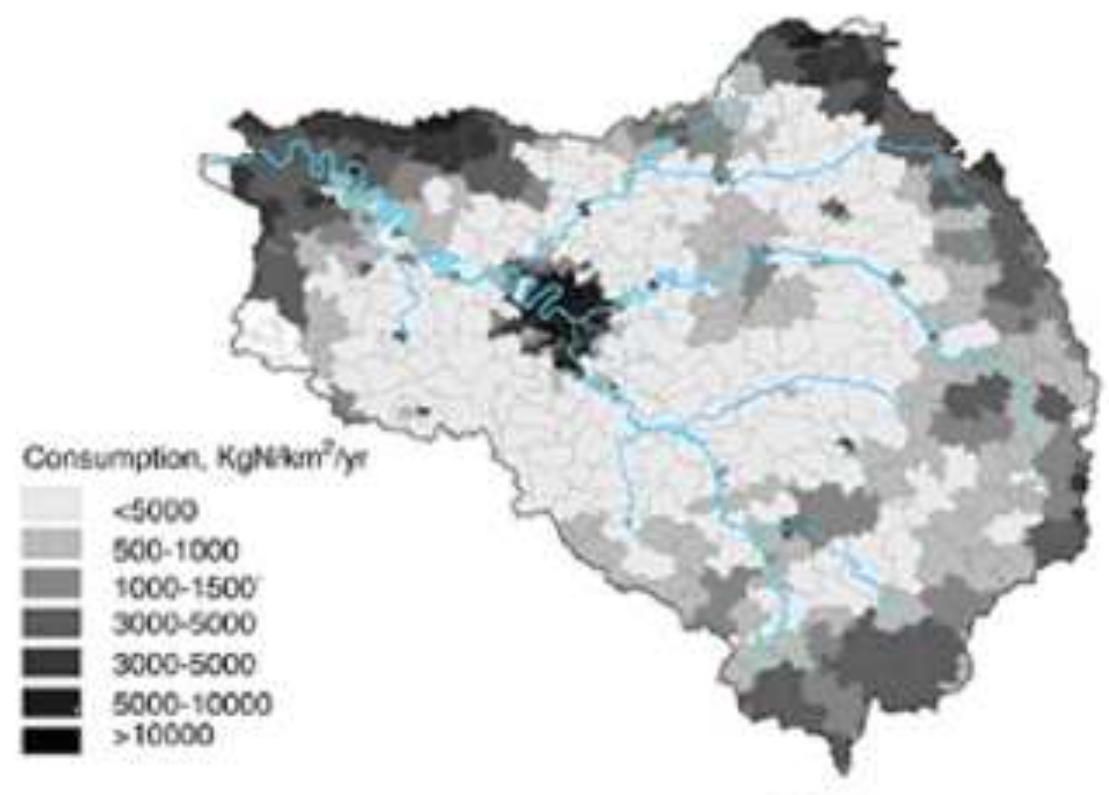

c.

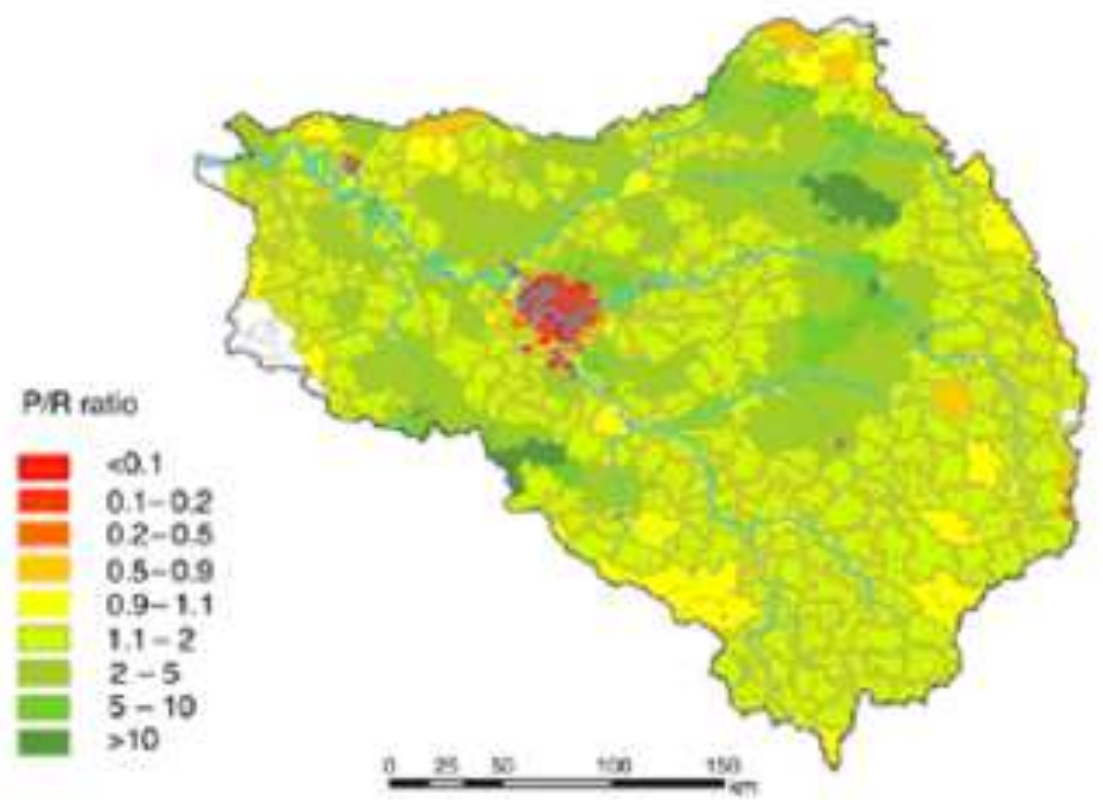




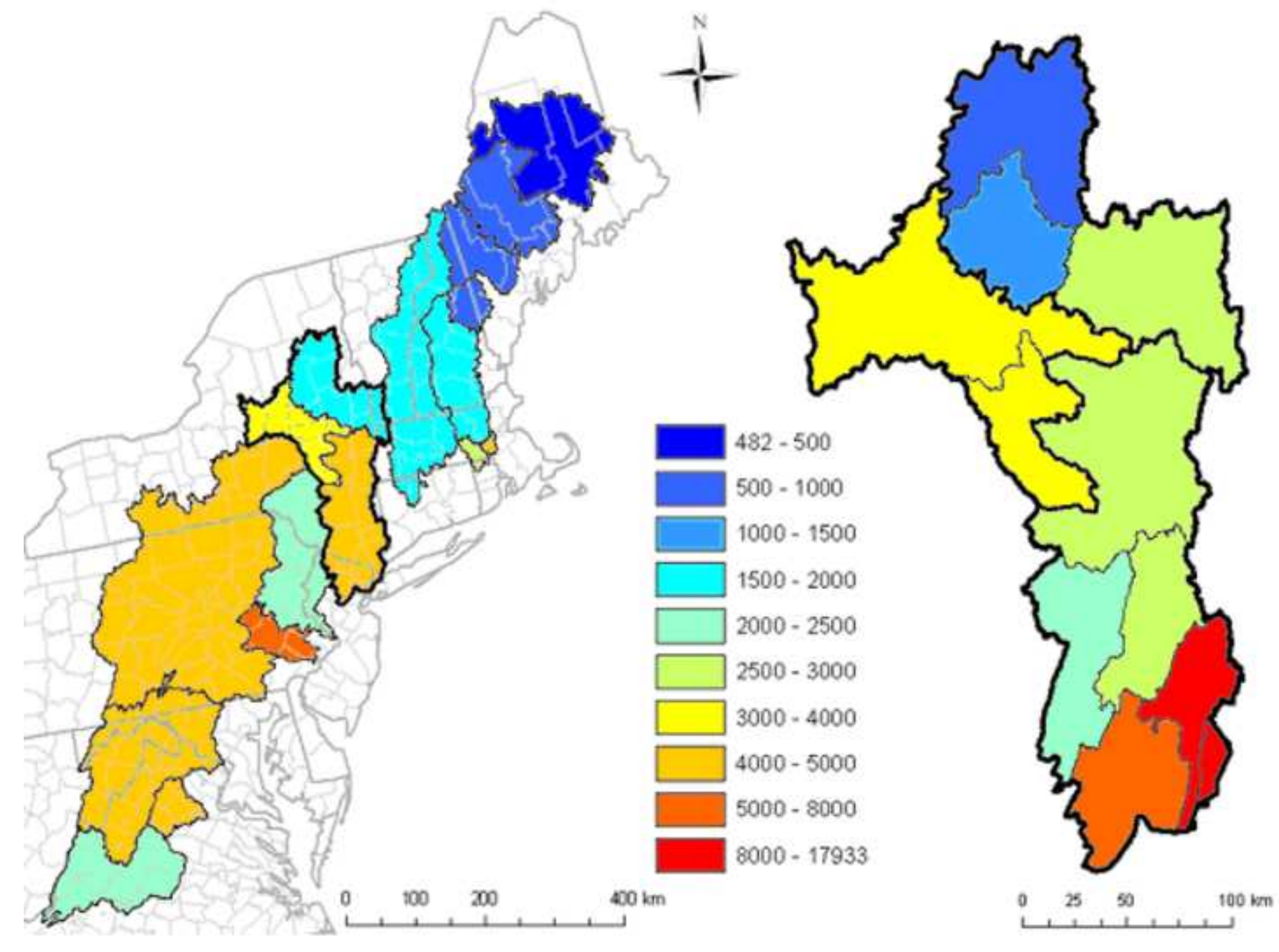


Click here to download high resolution image

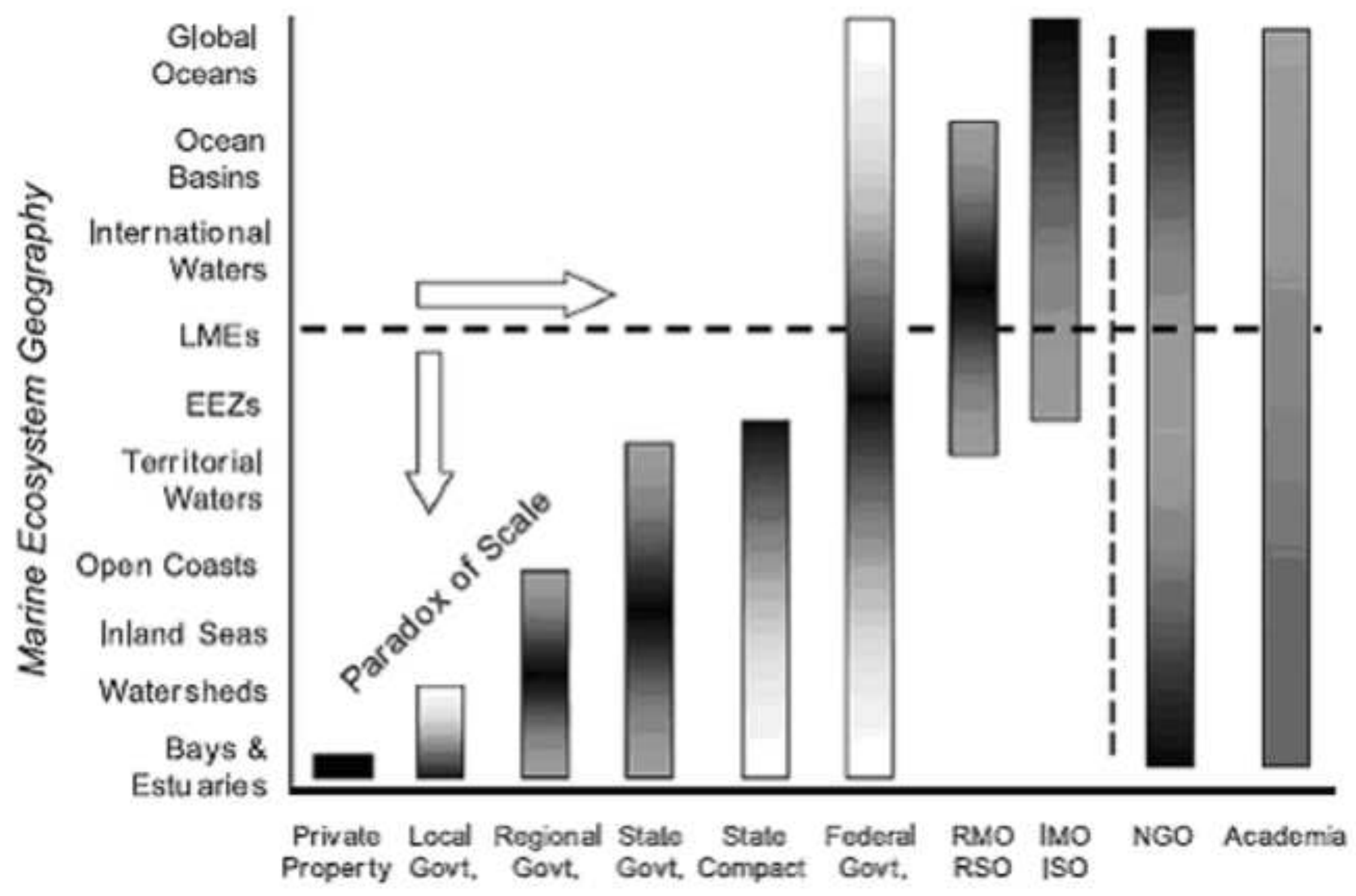

Govemance \& Advisory Services

Property Govt, Govt, Govt, Compact Govt, RSO ISO 


\section{Supplementary Material}

\section{Appendix 1. Terminology of Scale and Related Concepts (from Boynton et al., 2001)}

At a 1997 EPA/MEERC-sponsored workshop on "Scaling Relations in Experimental Ecology, held in St Michaels, Maryland, it was quickly recognized that the use of the terms "scale" and "scaling" varies widely across disciplines. In one of the papers emerging from the workshop, Boynton et al (2001) provide the following definitions, which seem suitable for discussions of coastal ecosystems.

\section{Definitions of Scale}

- A change in pattern is determined by the spatial and/or temporal extent of measurements necessary to detect significant differences in the variability of the quantity of interest (Gardner 1998).

- Scale refers to resolution (spatial grain, time step, or degree of complication) and to extent (in time, space, and number of components included) (Costanza et al. 1993).

- Scale denotes the resolution within the range of a measured quantity (Schneider 1994).

- Scale refers to the resolution (grain) and to the range (extent) of research activities and ecological rates (Schneider et al. 1997).

- Scale is defined by the temporal and spatial characteristics of energy and matter within and among ecological systems. The scale of a study is determined by the size and extent of the observations in time and space, as well as by the resolving power of the individual measurements (Hoekstra et al. 1991).

\section{Definitions of Scaling}

- Scaling refers to the application of information or models developed at one scale to problems at other scales (Costanza et al. 1993).

- Scaling is that which is needed when the "ballgame rules" change; when relationships break down when size (for example) changes and some other feature does not change in a linear fashion (from workshop notes).

- Scaling pertains to the use of rules to explain the manner in which processes change when extrapolating from short to long and small to large time and space scales; all measurements are related to scale (from workshop notes).

\section{Definitions of Scale-Dependence}

- Scale-dependent pattern can be defined as a change in some measure of pattern with a change in either the resolution or range of measurement (Schneider 1994).

- Scale-dependent pattern refers to the way in which statistical summarization of a quantity changes with spatial or temporal scale,

- Scale-dependent processes are those where the ratio of one rate to another varies with either resolution or range of measurement (Schneider 1994).

\section{Other Definitions}

- Extent is the overall area encompassed by a study.

- Grain is the size of the individual units of observation. Extent and grain define the upper and lower limits of resolution of a study (O'Neill et al. 1986).

- Allometric relationships are those wherein a part of an organism or a process is related to or scaled to another and the scaling is not a direct proportion (i.e., the. scaling factor is not unity); isometric relationships are those related by direct proportion (i.e., the scaling exponent is unity) (Calder 1983).

- Normalization is scaling that is done with simple direct proportions; identical with isometric scaling.

- The scope of a natural phenomenon is defined as the ratio of the upper to lower limit. Scope is thus the ratio of the extent to the grain or the ratio of the largest to the smallest size scale of measurement. Scope also provides an indication of the degree of extrapolation that is needed or used (Schneider 1998). 
- Multiscale analysis is simply the recognition that there is no single "right" scale for analysis at levels of organization above an individual organism (Schneider 1994).

\section{Appendix 2. Typology, Scale and Data}

Rob Nicholls, Roberto Pastres, and Paul Tett

\section{Aristotelian and Newtonian Views of the Coastal Zone}

"Classical categorization comes to us first from Plato, who, in his Statesman dialogue, introduces the approach of grouping objects based in their similar properties. This approach was further explored and systematized by Aristotle in his Categories treatise, where he analyzes the differences between classes and objects. Aristotle also applied intensively the classical categorization scheme in his approach to the classification of living beings ... establishing this way the basis for natural taxonomy..." (http://en.wikipedia.org/wiki/Categorization)

The European Water Framework Directive (WFD) concerns itself with the ecological and chemical status of water bodies, defined as "a discrete and significant element of surface water such as a lake, a reservoir, a stream, river or canal, part of a stream, river or canal, a transitional water or a stretch of coastal water." Chemical status involves comparisons with quality standards but ecological status requires assessment of deviation from type-specific reference conditions, and the aim of management is essentially to restore water bodies to something close to these conditions. Thus there are concrete water bodies - exemplified by the Scottish fjord, loch Creran - which instantiate types - Creran is a 'coastal water type $12^{\prime}$ in the system made by the UK and ROI (Tett, 2008). The quality status of the phytoplankton biological element in loch Creran will be assessed by comparison with reference data collected in another fjord, Loch Ewe, by an agency of the Scottish Government.

This approach has technical difficulties, e.g., there are some physical differences between loch Ewe and loch Creran: Why should we expect that they would have similar phytoplankton under undisturbed conditions? Such difficulties could be resolved with sufficient data and sub-typing, but the key point is that underlying this sort of categorization the philosophy that nature can be divided into discrete categories, each of which represents an ideal type, so that our management aim should be to maintain or restore the ideal. Key questions for this "Aristotelian" world-view are: what are the spatial limits of the water body or coastal zone system concerned, and, to what type does the water body or CZ system belong?

A contrasting world view, which sees nature as a continuum, could be called "Newtonian," because it is best described by the continuous differential equations of the Newtonian calculus. At any point in the continuum, conditions are a function of space, time and each other; the functions capture key features of processes relating each aspect of the local conditions (i.e. relating the state variables that define the system). In such cases, ecological theory can define a state of ecosystem "health", and social theory may be able to do the same for human societies; hence we may be able to characterize each point in the continuum as healthy or unhealthy, with an obvious preference for the first.

The new European Marine Strategy Framework Directive can (and perhaps should) be interpreted in Newtonian terms. The Directive requires good environmental status in 'salt-water' (not estuarine) regions out to the limits of national jurisdictions. This status is defined in part as that of "marine waters where these provide ecologically diverse and dynamic oceans and seas which are clean, healthy and productive within their intrinsic conditions, marine strategies; ...". The units of management are very large - for example, the North Sea is named as a sub-region within the North-East Atlantic region - and it is not yet clear how information on status will be aggregated even over sub-regions. Nevertheless it would be possible to define a set of indicators that could be used to measure ecosystem state and function at arbitrary locations, to define 'good health' for each location on the basis of its environmental conditions, thus to evaluate health at each place, and finally to define an averaging or aggregation procedure to be used over a sub-region.

\section{Typology: static versus dynamic characterization}

Defining a typology is important in comparing both system status and the outcomes of 
management policies. Typology implies classification, i.e. an Aristotelian view. Unfortunately, a classification usually implies a "static" characterization of coastal waters when, in fact, they are highly dynamic systems receiving fluxes of matter and energy from both local catchments and the sea which subsidize the maintenance of a coherent structure. Coastal ecosystems often rapidly respond to changes in these inputs during both periods of deterioration and recovery phases, so a challenge for typologies applied to coastal systems is to capture their dynamics with creative analysis of readily available data. Signs of change may be evident if we look at some indicators/indices of overall ecosystem functioning.

For example, introduction of invasive alien species marks an irreversible change in an ecosystem structure, but such a "perturbation" may be absorbed and, due to adaptive/evolutionary processes at different time scales, the ecosystem could maintain its functionality. The "alien" bivalve Tapes philippinarum was introduced to Northern Adriatic coastal lagoons about twenty years ago. In the lagoon of Venice, this species was successful, since the local species, Tapes decussatus, was disappearing due to the severe eutrophication episodes which repeatedly occurred in the Lagoon at that time. The reduction of $\mathrm{N}$ and $\mathrm{P}$ loads implemented in the 1980s, has markedly lowered nutrient concentrations, particularly $\mathrm{P}$, in lagoon waters, but has not brought back the native species. Overall, however, from the ecosystem point of view, a benthic filter feeder has substituted for a "functionally equivalent" one. Typologies aimed at characterizing ecosystem function must consider different indices than those aimed at distinguishing dominant species.

Because systematic variation in pressures/drivers induce corresponding variations in ecosystem states, typologies based on spatial or temporal "mean" values (or other statistical measures of central tendencies) of biological (phytoplankton density), chemical (nutrients, pollutants) or physical (residence times) variables, i.e. "quality elements" sensu WFD, may be misleading. Temporal averages over seasonal variations (temperature) or spatial averaging over "hotspots" (nutrient loads) especially in coastal basins with complex morphology or circulation pattern can miss critical dynamics and structures

that define the ecosystem. To adequately characterize such systems, typological systems should address time variation of systems, including indices of the "typical" seasonal evolution of both drivers/pressures on the system, and corresponding "state" indicators (ideally ones that are cheap and easily measured).

Where time series are available for the desired variables, these indices (and their trends) can be identified in a quantitative fashion and potentially can provide relevant information about the cause-effect relationships between systematic changes in drivers/pressures and changes of state. Typology can then be based on both the similarity of mean values and that of the seasonal patterns using Functional Data Analysis and clustering methods. It is worth noting that the most recent generation of typology software developed with support from LOICZ (DISCO, Buddemeier et al, 2008) has aimed to include time series data directly in analysis of typology, though such datasets have not yet been generally available for the coastal zone.

\section{Developing global and regional databases to support coastal science for management}

Process-based analyses of coastal zones allow us to understand how coastal systems operate, and move towards prognostic evaluation. Both these activities are important elements in providing the scientific basis for coastal management. Given the broad-scale of many of the drivers of coastal problems, investigations at these broad scales as well as local scales are important for a number of purposes, such as assessing and comparing impacts, as well as assessing the potential benefits of different policy interventions. This requires broad-scale databases with the necessary input data. However, the availability of such databases is generally a major constraint or even precludes application of process-based knowledge, especially for studies that address the land/sea interface (e.g., National Research Council, 2004).

Over the last two decades, the availability of digital spatial data has vastly increased as a result of advances in data capture and input techniques, and this has had a significant impact on coastal science. Fundamental to this is remote sensing. It has provided new and improved data for large parts of the world's coastal areas for physical factors such as wave climate, water quality, sediment fluxes, and elevation. At the same time, new gridded global datasets on various socio-economic parameters such as population distribution and GDP density are being developed and upgraded in order to satisfy data needs for interdisciplinary analysis. For some factors, global sources are extremely dated as this type of research has not been funded (e.g., the global geomorphic maps of Valentin (1952) and McGill (1958) 
which have never been updated). These datasets are normally typological in structure, and improvements are likely to have the same structure. Some factors, such as the long-term baseline rate of shoreline change are simply not known for large parts of the world's coast.

The DIVA, SAUP, LOICZ and CoastBase databases probably constitute the most comprehensive attempts to effectively merge coastal data, to date (see Table A2.1). The DIVA database is worthy of note as it builds on the other three (Vafeidis et al., 2008). It explicitly contains more socio-economic data, digitized sources from the old geomorphic data, and has a unique one-dimensional structure based on 12,148 coastal segments of variable length which captures the data. (This linear data structure is especially efficient for coastlines, compared to a raster structure; this is not true for coastal sea databases). This database feeds the DIVA models, which the database was designed to drive, and collectively this database-model system allows investigation of the potential impacts of sea-level rise. Nevertheless all the models are limited by the absence or limits of data which could greatly improve them.

Continued development of broad-scale data will be required to improve our scientific understanding of the world's coastal zones. Coastal geomorphological parameters are a particular gap in this regard and will require dedicated projects to fill; time series of driver, pressure, and state data are similarly important. These data developments will need to proceed in parallel with model and software development to insure that the critical data are collected; consideration of the best form of the database that encourages flexibility and ease of use will be essential. Coupled database/analysis systems, such as LOICZView and DISCO can facilitate both exploratory typological analyses and rapid refinements in typologies.

\begin{tabular}{|c|c|c|c|c|c|}
\hline Database & Coverage & Data Format & Resolution & Data Sources & Source \\
\hline $\begin{array}{l}\text { DIVA (Dynamic } \\
\text { Interactive } \\
\text { Vulnerability } \\
\text { Assessment) }\end{array}$ & $\begin{array}{l}\text { Coastal } \\
\text { areas } \\
\text { (coastline) }\end{array}$ & $\begin{array}{l}\text { Vector (one- } \\
\text { dimensional) }\end{array}$ & Variable & $\begin{array}{l}\text { Existing } \\
\text { datasets, including } \\
\text { synthesis of paper } \\
\text { sources }\end{array}$ & Vafeidis et al (2008) \\
\hline LOICZ typology & Global & Raster & Half degree & $\begin{array}{l}\text { Existing } \\
\text { datasets }\end{array}$ & $\begin{array}{l}\text { Maxwell and } \\
\text { Buddemeier (2001) }\end{array}$ \\
\hline $\begin{array}{l}\text { SAUP (Sea Arounc } \\
\text { Us Project) }\end{array}$ & $\begin{array}{l}\text { Coastal } \\
\text { areas and } \\
\text { Oceans }\end{array}$ & Raster & Half degree & $\begin{array}{l}\text { Existing datasets, } \\
\text { newly developed } \\
\text { datasets for SAUP }\end{array}$ & $\begin{array}{l}\text { www.saup.fisheries. } \\
\text { Alder (2003) }\end{array}$ \\
\hline $\begin{array}{l}\text { CoastBase } \\
\text { (European virtua } \\
\text { coastal and marine } \\
\text { data warehouse) } \\
\end{array}$ & Europe & Various & $\begin{array}{l}\text { Not } \\
\text { specified }\end{array}$ & Existing datasets & www.coastbase.org \\
\hline
\end{tabular}

Table A2.1: Example broad-scale coastal databases and their main characteristics.

\section{Supplementary Material References}

Alder, J. 2003. Putting the coast in the Sea Around Us Project. Sea Around Us Project Newsletter 15:1-2.

Calder, W.A. III., 1983. Ecological scaling: Mammals and birds. Annual Review of Ecology and Systematics 14, 213-230.

Costanza, R., Mageau, M., Ulanowicz, R.E., Wainger, L., 1993. Scaling aspects of modeling complex systems. MEERC synthesis paper. University of Maryland Center for Environmental Science, Cambridge, Maryland.

Gardner, R.H., 1998. Pattern, process, and the analysis of spatial scales. In: Peterson, D.L., Parker, V.T. (Eds.), Ecological Scale: Theory and practice. Columbia University Press, New York, pp. 17-34.

Hoekstra, T.W., Allen, T.F.H., Flather, C.H., 1991. Implicit scaling in ecological research. Bioscience 41, 148-154.

Maxwell B.A., Buddemeier, R.W., 2001. Coastal typology development with heterogeneous data sets. Regional Environmental Change 3, 77-87.

McGill, J.T., 1958. Map of coastal landforms of the world. Geographical Review 48, 402-405.

National Research Council., 2004. A geospatial framework for the coastal zone national needs for coastal mapping and charting. National Research Council, Washington, DC. 
O'Neill, R.V., DeAngelis, D.L., Wade, J.B., Allen, T.E.H., 1986. A hierarchical concept of ecosystems. Princeton University Press, Princeton, New Jersey.

Schneider, D.C., 1994. Quantitative Ecology: Spatial and Temporal Scaling. Academic Press, New York.

Schneider, D.C., Walters, R., Thrush, S., Dayton, P.K., 1997. Scale-up of ecological experiments: Density variation in the mobile bivalve Macomona liliana. Journal of Experimental Marine Biology and Ecology 216, 129-152.

Schneider, D.C., 1998. Applied scaling theory. In: Petersen, D.L., Parker, V.T. (Eds.), Ecological Scaling: Theory and Applications. Columbia University Press, New York. Pp 253-269.

Tett, P., 2008. Fish farm wastes in the ecosystem. In: Holmer, M., Black, K., Duarte, C.M., Marbà, N. and Karakassis, I., (Eds.), Aquaculture in the Ecosystem. Springer, Berlin, pp. 1-46.

Vafeidis, A.T., Nicholls, R. J., McFadden, L., Tol, R. S. J., Hinkel, J., Spencer, T., Grashoff, P. S., Boot, G., Klein, R.J. T., 2008. A new global coastal database for impact and vulnerability analysis to sealevel rise. Journal of Coastal Research 24, 917-924.

Valentin, H., 1952. Die Kusten der Erde. Petermanns Geographische Mitteilungen. 246. 